DOI: 10.7819/rbgn.v16i51.1651

Área Temática: Contabilidade e Controladoria

\title{
Presença francesa no Brasil no século XIX: análise dos arquivos contábeis da Casa Boris no período de 1872 a 1887
}

\author{
French Presence in Brazil in the Nineteenth Century: analysis of the accounting \\ archives of Casa Boris's in the period from 1872 to 1887
}

La presencia francesa en Brasil en el siglo XIX: análisis de los archivos de contabilidad de Casa Boris en el periodo de 1872 a 1887

\section{José Paulo Cosenza ${ }^{1}$ \\ Carlos Antonio De Rocchi ${ }^{2}$ \\ Carlos Antonio Campello Ribeiro ${ }^{3}$}

Recebido em 14 de maio de 2013 / Aprovado em 11 de julho de 2014

Editor responsável: Ivam Ricardo Peleias, Dr.

Processo de avaliação: Double Blind Review

\section{RESUMO}

Fundada no período imperial brasileiro, a Casa Boris teve importante papel comercial na região Nordeste do Brasil. Utilizando-se de uma estrutura comercial competitiva, unia a Província do Ceará (filial) à França (matriz), através da importação de produtos manufaturados e a exportação de matérias-primas. Neste trabalho, são pesquisados os livros Diário e Razão da Casa Boris, particularizados ao período 1872-1887. O estudo tem como objetivo analisar o conteúdo contábil dos registros efetuados nesses livros, de modo a relatar os fatos e aspectos de interesse histórico para a contabilidade brasileira. A principal contribuição da pesquisa, em termos gerais, está associada à tentativa de compreender a influência dos eventos políticos, econômicos, sociais e institucionais sobre as práticas contábeis e vice-versa. Os achados conduzem à conclusão de que a escrituração contábil da Casa Boris era transparente, a ponto de revelar a qualidade do controle contábil das operaçóes comerciais realizadas pela empresa e, também, mostrar a coexistência de um incipiente mercado provincial que ligou concomitantemente o Brasil à Europa no segundo período monárquico brasileiro.

Palavras-chave: História da contabilidade. Práticas contábeis. Brasil monárquico. Leis societárias. Empresas francesas.

1. Doutor em Contabilidade e Finanças pela Universidad de Zaragoza (Espanha). Título revalidado pela FEA/USP em Controladoria e Contabilidade. [jcosenza@vm.uff.br]

2. Doutor em Engenharia de Produçáo pela Universidade Federal de Santa Catarina (UFSC). [ca.rocchi@aol.com.br]

3. Doutor em História Social pela Universidade Federal do Rio de Janeiro (UFRJ). [Campello@vm.uff.br]

Endereço dos autores: Universidade Federal Fluminense (UFF). Rua Mário Santos Braga, 30 - 7 o andar - Sala 710 - Campus do Valonguinho - CEP 24020-140 - Niterói - RJ - Brasil 


\section{ABSTRACT}

Founded in Brazilian imperial period, Casa Boris had an important commercial role in the Northeast region of Brazil. Using a competitive business structure, it linked the Ceará Province (branch) with France (headquarters), by importing manufactured goods and exporting raw materials. In this paper, we studied the Journal and Ledger of Casa Boris, particularly from 1872 to 1887 . The study aimed to analyze the contents of the accounting records contained in these books so as to report facts and points of historical interest to the Brazilian Accounting. The main contribution of the research, in general, is associated with an attempt to understand the influence of political, economic, social and institutional settings on accounting practices and vice-versa. Our findings led to the conclusion that the bookkeeping of Casa Boris was transparent to reveal the quality of accounting control of commercial operations undertaken by the firm and also shows the coexistence of a incipient provincial market that concomitantly linked Brazil to Europe in the second period of Brazilian Monarchical Empire.

Keywords: Accounting history. Accounting practices. Monarchical Brazil. Commercial law. French firms.

\section{RESUMEN}

Fundada en el periodo imperial brasileño, Casa Boris tuvo papel comercial destacado en la región Nordeste de Brasil. Utilizándose de una estructura empresarial competitiva, ella unía la Provincia de Ceará (sucursal) con Francia (sede) mediante la importación de bienes manufacturados y la exportación de materias primas. En este trabajo se han estudiado los libros Diario y Mayor de la Casa Boris, relativos al periodo 1872-1887. El estudio tiene como objetivo analizar el contenido de los asientos contables apuntados en estos libros, buscando informar los hechos y puntos de interés histórico para la Contabilidad de Brasil. La principal aportación de la investigación, en general, se asocia al intento de comprender la influencia de los componentes políticos, económicos, sociales e institucionales sobre las prácticas de contabilidad y viceversa. Los resultados permiten concluir que la contabilidad de la Casa Boris era transparente hasta el punto de demostrar la calidad del control contable de las operaciones comerciales llevadas a cabo por esa empresa y también muestran la coexistencia de un mercado provincial incipiente que unía concomitantemente Brasil a Europa en el segundo periodo monárquico brasileño.

Palabras clave: Historia de la contabilidad. Actividad contable. Monarquía en Brasil. Derecho mercantil. Empresas francesas.

\section{INTRODUÇÃO}

Ao se olhar a literatura contábil sobre a história da contabilidade no século XIX, nota-se o predomínio de estudos relativos à questão da aplicação da Contabilidade de Custos e Gerencial, sobretudo no Reino Unido e países de língua inglesa. Para Fleischman e Tyson (2003, p. 44), barreiras linguísticas limitam a exposição de pesquisas sobre a história contábil tomando fontes primárias não inglesas. Esta situação ocorre porque a língua inglesa representa, tradicionalmente, o "idioma franco" na comunicação de pesquisas contábeis.

Do ponto de vista científico, o problema de pesquisa emerge ao se considerar que na mesma época em que países como França e Inglaterra passavam por um processo de revoluçáo industrial, do outro lado do Atlântico, no Brasil, ainda se vivia sob um contexto econômico de predomínio de relações comerciais e prestação de serviços, mas se apresentava um padrão de conduta contábil com grande semelhança ao modelo contábil europeu (em termos de estrutura e contas contábeis), conforme será ilustrado por meio da empresa pesquisada neste trabalho.

Esta pesquisa foi estruturada de forma a se analisar os aspectos contábeis e societários implícitos nas práticas contábeis adotadas por uma empresa comercial que atuou no ramo de comércio atacadista, vendendo manufaturados importados e comprando matérias-primas para 
exportação, e ocupou uma posição privilegiada na região Nordeste, durante o segundo reinado do governo imperial brasileiro.

O objetivo deste estudo consiste em analisar o conteúdo dos registros efetuados nos livros contábeis dessa casa de comércio, no período entre 1872 e 1887, para compreender os fatos e aspectos retratados nas práticas contábeis e a vinculação e relação da contabilidade com os eventos econômicos, políticos, sociais e institucionais e vice-versa.

Para isso, a pesquisa foi estruturada em oito seçôes, incluindo esta introdução. Na seção 2, são descritos os fatores que induziram a expansão comercial francesa no século XIX. A terceira seção apresenta uma breve consideração sobre o papel dos comerciantes franceses no Brasil Imperial. $\mathrm{Na}$ quarta seção, faz-se uma rápida caracterização da Boris Frères \& Ltd. Co. (popularmente conhecida como Casa Boris, designação que será utilizada neste artigo) em seus aspectos societários e mercantis. Na seção seguinte, realiza-se um relato sucinto contextualizando o core business da Casa Boris e sua importância econômica, social e política no Ceará. A sexta seção trata dos aspectos metodológicos aplicáveis à pesquisa e, em seguida, na sétima seção, são analisados alguns registros contábeis de interesse teórico contábil e profissional, encontrados nos documentos contábeis que basearam a pesquisa. Finalmente, na última seção, as conclusôes e consideraçôes finais sobre o assunto são apresentadas, complementadas pelas referências bibliográficas utilizadas no estudo.

\section{ESTRATÉ G I A COMERCIAL FRANCESA NO SÉCULO XIX}

De 1850 até o final do século XIX, a presença comercial francesa começou a se expandir, conquistando uma posição de destaque no cenário internacional. Para Monteiro (1998, p. 56), dentre as razóes determinantes dessa forte evolução no comércio exterior pode ser citado como fundamental o programa interno de reformas sociodemocráticas, que terminou estimulando uma política externa voltada para a expansão colonial, alicerçada no crescimento econômico com base no progresso industrial-tecnológico e no comércio exterior. De acordo com Monteiro (1994), essa estratégia conduziu a França a uma posição privilegiada nas relaçôes comerciais externas, especialmente com países de outros continentes, como foi o caso do Brasil. Nessa época, a balança comercial entre França e Brasil, segundo Rocha e Gandara (2009, p. 292), apresentava um movimento de importação e exportação de mercadorias só superado pelo comércio brasileiro realizado com a Inglaterra.

Sublinhe-se, no entanto, que a significativa competitividade comercial francesa foi, em parte, vinculada ao papel exercido pelos chamados "comissários em mercadorias” na França, associados com imigrantes franceses (MONTEIRO, 1998). Ao longo do processo expansionista francês, eles fundaram pequenas casas comerciais que ocuparam destacado papel econômico, atuando no segmento importador-exportador de produtos e mercadorias.

Concomitante a esse movimento de expansão comercial francês, Rego (2010, p. 175) assinala a existência de um articulado processo interno de evolução socioeconômica da França como um todo, que propiciou uma experiência de desenvolvimento econômico nacional unificada baseada em um eficiente sistema de transporte ferroviário e marítimo e uma rede telegráfica instalada que cobria totalmente o território francês. Para Rego (2010, p. 176), a comunicação instantânea do pensamento, simultaneamente com o transporte rápido das pessoas e das coisas, operou uma verdadeira revolução no comércio da França, servindo de estímulo à realização de investimentos de capital e trabalho no exterior. Conforme Rocha e Gandara (2009, p. 291), a constituição de empreendimentos dedicados ao comércio de importação e exportação, ligados às matrizes francesas e estabelecidos sob a forma de casas de comércio, respondeu por boa parte da emigração francesa em direção ao Novo Mundo.

No Brasil, essas casas comerciais tiveram importância fundamental na corroboração dessa política expansionista francesa. Conforme Bertelli (2006), os comerciantes franceses atuavam como atacadistas e se organizavam estruturalmente com 
uma matriz localizada naquele país europeu e uma filial em solo brasileiro, conseguindo, assim, gozar de fortes vantagens estratégicas competitivas. Assim, a relação comercial direta França-Brasil, no século XIX, foi favorecida, em boa parte, pelo movimento migratório de judeus-franceses que se dedicaram principalmente ao comércio nos principais centros urbanos brasileiros e pela possibilidade de se efetuar o transporte marítimo das mercadorias e produtos por meio de uma rota de navegação segura e direta, minimizando, assim, os riscos de perdas e reduzindo os custos de escalas em outros portos no litoral ocidental.

De acordo com Martins (2009, p. 27), a vinda de comerciantes franceses para o Brasil, no século XIX, pode ser vista como resultado de movimentos preliminarmente direcionados para pontos geográficos específicos, motivados pela possibilidade de exploração comercial do Novo Mundo. As primeiras levas do movimento emigratório francês datam do final das guerras napoleônicas, quando este lado do Atlântico foi percebido como território para novas oportunidades de trabalho, cabendo a esses especiais imigrantes darem o tom de civilidade e aperfeiçoamento de serviços especializados, em particular no comércio fino (MARTINS, 2009, p. 29).

\section{OS COMERCIANTES FRANCESES NO BRASIL IMPÉRIO}

Conforme Almeida (2003, p. 2), a lei e os costumes brasileiros estabeleciam certas restriçóes ao exercício do trabalho estrangeiro no Brasil Imperial. No entanto, excepcionalmente na atividade comercial, qualquer estrangeiro podia se tornar comerciante no país, gozando dos mesmos direitos e prerrogativas que os cidadáos nacionais. Segundo o autor, em certos momentos históricos ou lugares determinados essa excepcionalidade e liberdade de participação do capital estrangeiro, sobretudo o europeu, em atividades como o comércio de varejo, representou focos de tensão em razão do monopólio econômico, despertando a animosidade, ou mesmo a hostilidade, dos locais.

Os investimentos franceses no Brasil durante o século XIX foram muito acentuados no comércio varejista, principalmente no Rio de Janeiro, o que propiciaria, na opinião de Mauro (1999, p. 85), condiçôes para a constituição de uma comunidade francesa que criaria a atmosfera favorável para o estabelecimento de empresas maiores. A acumulaçáo do capital oriunda da atividade comercial favoreceu a expansão dos negócios, e surgiram organizaçôes de maior porte como bancos, seguradoras e firmas importador-exportadoras.

Como boa parcela das receitas do Estado advinha de impostos cobrados sobre importaçôes, a voz dos comerciantes se tornou ainda mais forte e relevante para aqueles preocupados com assuntos estatais (SABA, 2010, p. 78). O Código Comercial Brasileiro de 1850 veio dar o selo de oficialidade à ligação dos vínculos entre negociantes e autoridades.

Não foi só no Rio de Janeiro, contudo, que os franceses se estabeleceram; também no Ceará esses imigrantes estiveram presentes. No rastro do desenvolvimento brasileiro, a economia cearense também cresceu e se diversificou nesse período (GIRÃO, 1968). Durante essa fase, entretanto, são apenas dois os produtos mais significativos na pauta de produtos de exportação nordestinos pelo porto de Fortaleza, na época o mais importante canal para o escoamento da produção agrícola regional. Conforme Girão (2000), esses produtos eram o algodão e o açúcar, embora houvesse também embarques de cera de carnaúba, sal, cacau, mamona, couros, ossos, chifres e garras. Já o fluxo de importação referia-se predominantemente a tecidos, peças de vestuário, produtos de perfumaria, objetos de decoração, vinhos, conservas, manteiga, farinha de trigo, drogas, artigos de armarinho e materiais de papelaria.

Com a movimentação portuária, cresceu a infraestrutura urbana, aumentaram as relaçôes capitalistas e, assim, formou-se uma elite. Segundo Menezes (2006, p. 29), esses eficazes "senhores do progresso" apareceram com mais força em Fortaleza a partir da década de 1860 e estabeleceram suas redes de relações mais efetivamente na década de 1870. Para Takeya (1995, p. 116-135), a instalação da Casa Boris na Província do Ceará, em 1872, foi um grande exemplo da 
complementariedade de interesses privados com os da elite local.

A opção da família Boris por Fortaleza contrastava com a preferência dos investidores franceses. Em geral, depois do Rio de Janeiro, a capital do Império, eles tinham preferência pelas cidades de Recife e Salvador. Todavia, a opção diferenciada da Boris Fréres pela cidade de Fortaleza colocou-os próximos dos círculos das decisões político-administrativas da província, o que se revelaria, mais tarde, uma decisão extremamente acertada e fecunda, em função de seus interesses no Ceará (MENEZES, 2006, p. 30).

A expansão da economia do Ceará entre 1860 e 1870 significava para a Casa Boris, conforme Bertelli (2006), a possibilidade de atuar não só no ramo da exportação de matérias-primas para a Europa mas também no ramo de importação de produtos manufaturados para uma regiáo brasileira cujo consumidor carecia da oferta de produtos franceses, sobretudo os artigos ditos de "luxo", como os de perfumaria, as peças de vestuário e os objetos de decoração, além de vinhos e conservas. Isso iria possibilitar-lhe, paulatinamente, maior competitividade, com a conquista de uma posição privilegiada frente às novas casas comerciais francesas que com ele ali se instalavam.

\section{CARACTERIZAÇÃO DO EMPREENDIMENTO MERCANTIL}

Conforme Monteiro (2009, p. 253), a família Boris teve sua origem histórica ligada à cidade de Chambrey, na região da Alsácia-Lorena, fronteira com a atual Alemanha, regiáo responsável pela imigração da maioria dos judeus que vieram para o Brasil. Sobre a emigração de franceses para o Brasil, segundo Fridman (2009, p. 178), ela foi composta por viajantes, naturalistas, cientistas, cronistas, artistas, comerciantes e impressores, tendo principalmente destino urbano. Esses franceses imigraram em função da guerra franco-prussiana, já que muitos deles se recusaram a aceitar a nacionalidade alemá, com a conquista da soberania daquela região pela Alemanha (FRIDMAN, 2009).
O patriarca dos Boris, Moyse Abrahan, nasceu em Cernay, no ano de 1734. De acordo com Monteiro (2009, p. 254), ele era um mercador de cavalos, em Chambrey, que adotou o sobrenome Boris, por ocasiáo de extensão dos direitos de cidadania aos judeus franceses na Revolução Francesa. Dentre seus netos, nasceu Isaac Boris, em 1789, que além de adotar a profissão de mercador de animais do avô, tornou-se Conselheiro Municipal em Chambrey e teve cinco filhos, sendo um deles Joseph Boris, pai dos cinco irmãos responsáveis pela Casa Boris (Theodore, Alphonse, Isaye e os caçulas gêmeos Achille e Adrien, nascidos nessa ordem). ${ }^{1}$

Alphonse e Theodore chegaram a Fortaleza em 1865 e 1867, respectivamente, com o primeiro vindo pelo Rio de Janeiro e o segundo por Recife (MOTA, 1982, p.12). Logo depois, em 1869, esses irmãos fundaram na cidade a casa de comércio Theodore Boris \& Irmão, que tinha como principal atividade as permutas comerciais (SABA, 2010, p. 36). Em função da guerra franco-prussiana (1870-1871), porém, eles retornaram para a França um ano depois. Posteriormente, em 14 de fevereiro de 1872 , junto com o irmão Isaye, eles fundaram em Paris a denominada Sociète Boris Frères, uma sociedade em nome coletivo, com um capital social de 300 milhóes de francos.

Ainda no ano de 1872, acompanhado do irmáo Adrien, Theodore retornou ao Brasil e, com a posterior chegada de Achille, fundou na Rua da Palma, no centro comercial de Fortaleza, a casa filial da matriz francesa, que ficaria popularmente conhecida como Casa Boris (MONTEIRO, 2009, p. 259). É importante observar que a família Boris deslocou-se economicamente em duas vertentes geográficas, uma situada na capital francesa e a outra em Fortaleza. A Casa Boris foi, portanto, um investimento francês realizado a partir de 1872, com instalaçóes na província do Ceará, em Fortaleza, que acabou se tornando uma das mais conceituadas casas de comércio estrangeiras dedicadas aos negócios de importação e exportação no Nordeste do Brasil do século XIX.

A estratégia de comercialização da Casa Boris foi engendrada baseada em uma hierarquia de distribuição das mercadorias importadas e dos 
produtos locais para exportação alicerçada na casa matriz de Paris, em uma das extremidades, e em um agente, que era o pequeno comerciante do interior da província na outra ponta, com a Casa Boris fazendo a interligação entre ambas. Para Monteiro (2009, p. 261), a atuação no grande comércio atacadista, vendendo manufaturados importados ou comprando matérias-primas para exportação apoiada preferencialmente na estrutura matriz-filial, foi o que distinguiu a Casa Boris de suas demais concorrentes, dando-lhe vantagens competitivas para atuar em dois mercados-polos (Paris e Fortaleza) e garantindo-lhe sua contínua expansão e sobrevivência durante décadas seguidas.

Barroso (1973, p. 17) assinala que a filial brasileira, sob a gerência dos irmáos Isaye, Adrien e Achille, acabou progredindo muito mais que sua congênere de Paris, dirigida pelos irmãos mais velhos e experientes (Theodore e Alphonse). Mota (1982, p. 17), todavia, assinala que, no decorrer do ano de 1917, a Casa Boris, por imperativo interno de reformulação, passou a se denominar Boris Frères \& Cia, continuando com os negócios de exportação, agências de seguros, navegação, afretamentos e estivas, exploraçóes agrícolas no interior do Ceará e crepagem de borracha. A atividade de importação já havia sido suspensa em 1910.

O fato é que a estrutura organizacional constituída por uma matriz francesa e uma filial brasileira, sob o controle societário de uma mesma família estabelecida nos dois lados do Atlântico, seria extinta em 1925 . Só em $1^{\circ}$ de setembro de 1927, porém, é que o relacionamento matriz-filial acabou cessando totalmente, com a liquidação da sociedade por causa da saída dos herdeiros do sócio Isaye. Com isso, nova firma foi constituída, a estratégia remodelada e os negócios do grupo divididos em dois ramos: Boris Frères \& Cia, com sede em Paris, à Rue de La Victoire, 65; e Boris Frères \& Cia. Ltda., com sede em Fortaleza (escritório e armazém à Rua Boris, 10), recebendo os ativos e responsabilizando-se pelos passivos da antiga empresa.

A empresa brasileira, que tinha como sócios e administradores Theodore Boris (o mais velho dos irmãos e último a falecer, em 1933), Georges Boris (filho de Theodore), Adrien Seligman (sobrinho vindo da França), Joseph Boris (sobrinho vindo dos EUA) e Bertrand Alphonse Boris (filho de Achille), se dedicaria ao comércio de importação e exportação em grande escala (como comissionada ou em consignação) e também atuaria como representante comercial de diversos bancos e casas bancárias e seria agente comissária de várias companhias de seguros estrangeiras.

Em 1930, a Casa Boris suspendeu as atividades de exportação em razão das dificuldades econômicas provocadas pela grande depressão de 1929. Isso acabou implicando a diminuição do fluxo de produtos cearenses para o exterior e forçou a concentração de esforços no incremento de novas oportunidades de negócio nos segmentos de agências de vapor e estivagem, investimentos imobiliários e exploração agrícola (MOTA, 1982, p. 18-19). Essas novas atividades progrediram com êxito e passaram a agregar bastante valor aos negócios da Casa Boris. Consequentemente, houve uma nova reestruturação societária, tendo sido criadas empresas consonantes com os objetivos de progresso almejados na estratégia corporativa dos Boris: 
QUADRO 1 - Estrutura Societária da Casa Boris - 1930

\begin{tabular}{|c|c|}
\hline Empreendimento & Atividade \\
\hline Boris Frères \& Cia. Ltda. & $\begin{array}{l}\text { - Proprietária de imóveis urbanos } \\
\text { - Agente de companhias de seguros marítimos e terrestres (Companhia de Seguros Maríti- } \\
\text { mos e Terrestre Confiança; Esperança - Companhia de Seguros; e Companhia de Seguros } \\
\text { Riachuelo) } \\
\text { - Agente de avarias (Comitè Central des Assureurs Maritimes) } \\
\text { - Representante do Bureau Veritas } \\
\text { - Retomada de suas tradicionais exportaçôes de couros e peles }\end{array}$ \\
\hline Boris Navegação Ltda. & $\begin{array}{l}\text { - Representante de numerosas companhias de navegação (Frota Nacional de Petroleiros, } \\
\text { Companhia de Navegação Marítima Netumar, Empresa de Navegação Aliança S.A; Nave- } \\
\text { gaçáo Mercantil S.A.; Moore McComarck Lines Inc.; Serviços d'Affretement Atlantique } \\
\text { Sud - S.E.A.S.; Wilson Sons \& Co. Ltd. Londres; Esso International Corp.; Johnson Line; } \\
\text { Royal Interocan Line e diversas outras linhas estrangeiras) } \\
\text { - Fornecimento de serviços de estiva }\end{array}$ \\
\hline Fazenda Serra Verde Ltda. & - Produção de algodão, cana-de-açúcar e gêneros alimentícios de origem agrícola \\
\hline Fazenda Agropecuária Serra Verde S.A. & - Criação e engorda de bois e porcos \\
\hline $\begin{array}{l}\text { Comercial de Produtos Agroindustriais } \\
\text { Ltda. (Copral) }\end{array}$ & - Distribuidora de produtos químicos para uso doméstico \\
\hline
\end{tabular}

Fonte: Elaboração própria.

A crise capitalista que se seguiu à grande depressão de 1929 gerou, no entanto, uma conjuntura de acirramento da competitividade econômica internacional. Tal quadro ampliou-se com a questão da linha de sucessão na direção dos negócios dos Boris. A esses fatores somou-se outro de caráter político, que foi o antissemitismo predominante por causa do advento do domínio nazista na Europa, responsável pelo golpe definitivo que determinaria a eliminação física da matriz na França. De acordo com Monteiro (2009, p. 267), a empresa em Paris desapareceria no contexto do sequestro dos bens judeus no início da década de 1940 e, com ela, toda sua documentação contábil. A conjugação de todos esses aspectos, concomitantemente, resultaria no "lance fatal" para as atividades comerciais da Boris Frères Paris, atingindo indiretamente as atividades da Casa Boris no Ceará, que entraria, a partir de então, em um processo de declínio até sua completa extinção na década de 1980 .

\section{IMPORTÂNCIA ECONÔMICA DA ATUAÇÃO DA CASA BORIS}

As casas de comércio desempenharam relevante papel na história econômica do Ceará e dos Estados vizinhos. A Casa Boris foi um dos empreendimentos mercantis constituídos nesse sentido, tendo assumido posição de realce na economia cearense, especialmente nos últimos dezoito anos do Segundo Império e nos dez primeiros da Primeira República (MAURO, 1999, p. 86). Em face do forte laço comercial mantido com sua matriz na França, essa firma realizou expressivas transaçóes de comércio de importação e exportação nas localidades mais importantes da Província do Ceará. Mota (1982, p. 9) escreve que a atuação comercial da Casa Boris abrangia especialmente as cidades de Fortaleza, Aracati, Sobral, Icó, Camocim e Itapipoca, mas ela também atuava em Estados do Nordeste (Pernambuco, Paraíba, Maranhão, Rio Grande do Norte e Bahia), do Norte (Piauí e Pará) e do Sudeste (Rio de Janeiro). 
INFLUÊNCIA NA GESTÃO

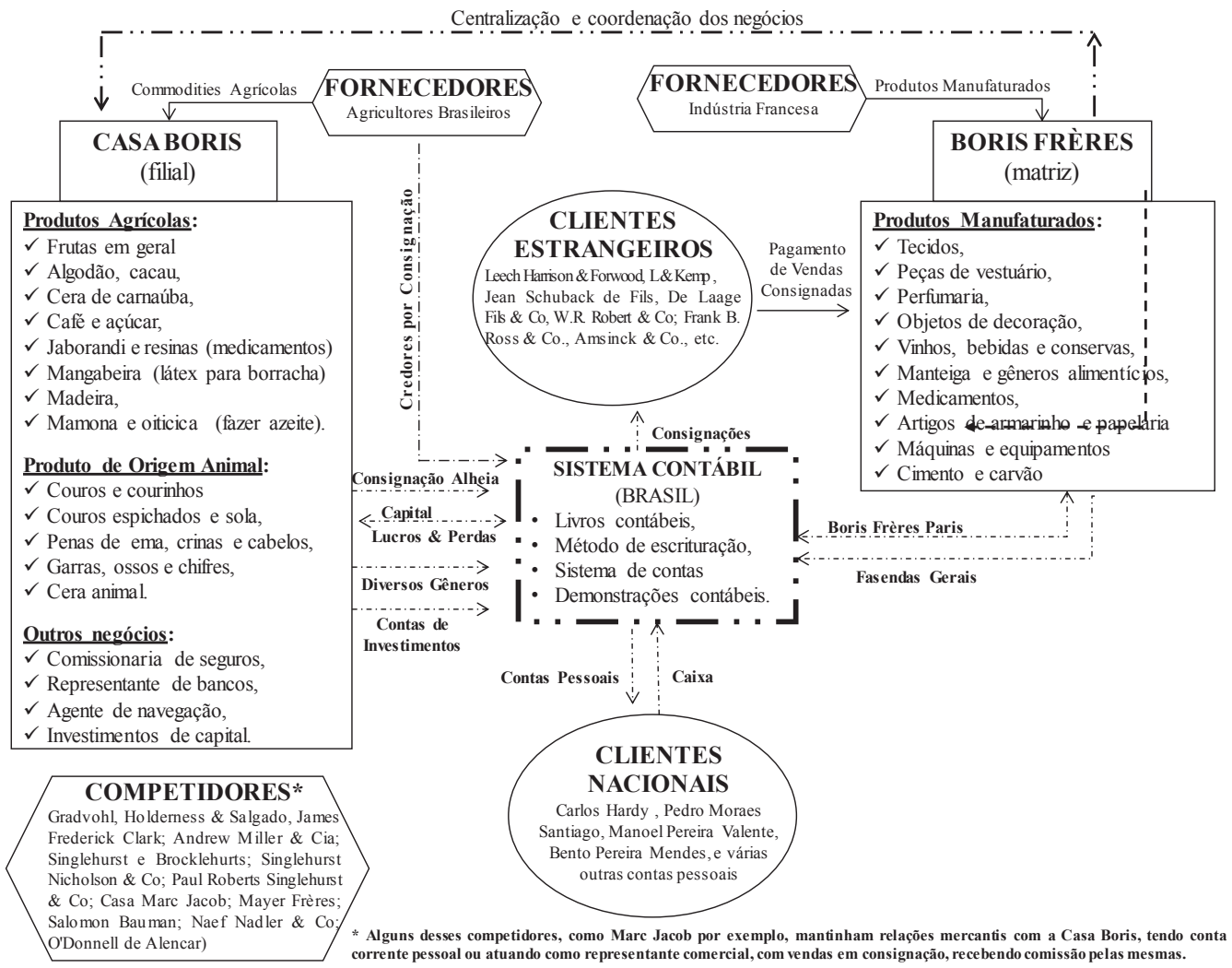

FIGURA 1 - Inter-relação entre estrutura de negócio e mecanismo contábil

Fonte: Elaboração própria.

De acordo com Barroso (1973, p. 16), a criação da Casa Boris resultou da estratégia da família Boris de expandir suas atividades para as Américas. Essa decisão implicou a criação de uma empresa totalmente articulada com a matriz de Paris. A matriz francesa era centralizadora dos negócios e também responsável pela coordenação das duas empresas mercantis, sendo as atividades de ambas as empresas tratadas de forma integrada, visando ao perfeito domínio dos dois principais mercados de atuação da família - o francês e o brasileiro. A filial brasileira exportava os principais gêneros do país para portos nacionais e estrangeiros e importava, principalmente, produtos manufaturados franceses.

A maioria dos produtos agrícolas para exportação ao mercado externo chegava até a Casa Boris por intermédio de produtores rurais interioranos locais (TAKEYA, 1994, p. 120). Conforme Bertelli (2006), alguns produtos mais específicos também foram comercializados, como o "jaborandi" e as "resinas", ambos empregados na fabricação de medicamentos. A Casa Boris também comercializou outros produtos de origem animal, como velas de cera de carnaúba e charque, e ainda aguardente. Depois dos tecidos, os couros foram os produtos mais comercializados pela Casa Boris, sendo um dos principais itens da pauta das exportaçóes brasileiras para a França. A cera de carnaúba e a borracha também foram comercializadas nas exportaçôes, embora em grau bem menor. Por outro lado, os objetos trabalhados com essa matéria-prima constituíram, segundo Bertelli (2006), uma das oito mais importantes mercadorias importadas daquele país pelo Brasil, no período. Em terceiro lugar, vinham as penas de ema, utilizadas na França, provavelmente, na indústria de decoração e vestuário.

As importaçóes contemplavam produtos manufaturados cujas encomendas eram feitas 
diretamente à casa-matriz. Ainda segundo Bertelli (2006), produtos oriundos de outros países também faziam parte do portfólio de produtos comercializados pela filial de Fortaleza, sendo a farinha de trigo vinda do mercado norte-americano um item bastante vendido para a confecção de pães e de bolacha. Embora atuando no ramo atacadista de importação-exportação, o citado autor assinala que a Casa Boris, através do comércio por comissôes e consignaçôes, também foi comissionária de várias companhias de seguros estrangeiras e representou diversas casas bancárias e bancos, nacionais e estrangeiros, sendo um deles o Banco do Brasil.

De acordo com Monteiro (1998, p. 60), a partir do ano de 1884 a família Boris passou a representar os interesses consulares da França na província do Ceará, representação esta que se estendeu ininterruptamente até 1925 e, depois, de 1928 a 1977. Monteiro (2009, p. 256) relata que a função do corpo consular francês era produzir informaçôes sobre as potencialidades econômicas do Brasil como mercado para produtos franceses, para serem divulgadas para os negociantes da França, em geral por diferentes canais institucionais.

Observa-se, ainda, que por conta da posição da Casa Boris na economia do Ceará existiu uma forte ligação com a elite cearense, inclusive com apoio a políticos locais (MENEZES, 2006), motivo pelo qual o acervo documental contábil preservado da Casa Boris ajuda a explicar historicamente a tentativa de expansão comercial francesa para o Brasil, de forma especial a política de inversão de capital e trabalho francês em Fortaleza no período monárquico brasileiro.

É importante destacar que a Casa Boris teve papel de destaque nas atividades econômicas da antiga Província do Ceara e nas primeiras décadas de existência do atual Estado do Ceara (realizando o comércio de importação e exportação, além de possuir agências de seguros e navegação e fábricas). Por outro lado, ela manteve também estreitas relaçóes com a oligarquia e a classe política cearense, sendo responsável por prover incentivos financeiros e intermediar a compra de materiais para construção de obras públicas na região (MORAIS, 2009, p. 26-27). A importância e o poder da Casa Boris, de acordo com Monteiro
(2009, p. 253), podem ser expressos na seguinte frase popular: "o mar do Ceará [foi] o açude da família Boris, e a Justiça, a sua mãe”.

Para Monteiro (2009, p. 262), a compreensão da trajetória das atividades mercantis da Casa Boris passa primeiro pelo entendimento do quadro comercial cearense referente às atividades de importação e exportação na base capitalista do sistema econômico vigente no segundo período imperial brasileiro, bem como dos demais aspectos da sociedade brasileira que iam sendo moldados por ele. Competindo com tradicionais empreendimentos locais e outras casas comerciais inglesas e francesas regionais, Mota (1982, p. 10) assinala que, simultaneamente ao desempenho da atividade de importação de mercadorias para consumo local e interestadual, ou seja, produtos necessários à época, a Casa Boris exportava produtos cearenses para a França, Inglaterra, Alemanha, Estados Unidos etc., e também atuava como agente de companhias de seguros e de navegação, além de investir em projetos agroindustriais, estradas de ferro, exploração de minas e atuar como casa bancária.

De acordo com Monteiro (2009, p. 266), o período 1880-1930 representou uma etapa de consolidação e, depois, o início do declínio das atividades comerciais da Casa Boris, no Ceará. O casamento de seus interesses com os da elite política do Ceará reforçou seu poderio econômico e deu-lhe importância cada vez maior no cenário econômico cearense. Sua atuação, a partir de 1880, como agente de companhias de seguros e de navegação (ex.: a francesa Chargeurs Réunis e a alemã Hamburgo Suedamerikanische) e também como representante dos interesses consulares franceses na Província, além da participação no setor de agroindústria, revigorou seus elos com o mercado internacional e fortaleceu sua influência política no eixo Paris-Fortaleza, reforçando ainda mais seu poderio econômico e influência na Província do Ceará.

Tais fatos conduziram-na ao exercício de um papel ativo no contexto da economia cearense, participando do fomento de novas atividades no setor de agroindústria (investimentos diretos na agricultura e no beneficiamento de produtos 
agrícolas) e de projetos de construção de estradas de ferro e obras públicas. Segundo Monteiro (2009, p. 266), a Casa Boris atuou como credora do próprio Governo Provincial/Estadual, ao tornar viável a execução de diferentes serviços públicos, e atuou no campo da captação de capital, via empréstimos externos, agenciando linhas de financiamento para o Governo do Ceará junto a grandes bancos europeus, especialmente um empréstimo realizado com o Banque Louis Dreyfus et Compagnie, na França. Esse contrato, firmado em 1910, visava prover o capital necessário para a execução do serviço de águas e esgotos de Fortaleza, sendo dado em garantia à Casa Boris rendas do Estado e direitos sobre impostos de exportação.

As condiçôes desfavoráveis do mercado internacional, associadas às questóes ligadas à linha sucessória na direção dos negócios, levaram, no entanto, a Casa Boris ao declínio de suas atividades comerciais, mais fortemente a partir da década de 1920, culminando com sua liquidação em 1984. Conforme Monteiro (2009, p. 267), em razão de a França perder progressivamente posição no mercado mundial, os negócios da Casa Boris acabaram sendo afetados, levando-a ao encerramento do comércio de importação em 1910, e por causa da crise do capitalismo que se seguiu à grande depressão de 1929, ao término das exportaçôes em 1930, o que fez que as atividades da Boris Frères, no Ceará, ficassem restritas unicamente ao ramo de navegação e seguros.

\section{METODOLOGIA}

No desenvolvimento deste trabalho, os autores seguiram a orientação sugerida por Christopher J. Napier, que compara o papel do historiador com o de um auditor. Segundo Napier (2002), o pesquisador da história contábil deve se comportar como um auditor, procurando entender o "como" e o "porquê" de os fatos contabilizados interagirem com o ambiente econômico e social no qual as entidades analisadas estão inseridas, promovendo modificaçóes e o desenvolvimento do entorno.
Conforme Hammond (2003), de duas décadas para cá as pesquisas em contabilidade estão, cada vez mais, caminhando em direçôes totalmente inesperadas. Apesar da maioria das instituiçôes acadêmicas e revistas de contabilidade deixar de apreciar as contribuiçóes dos segmentos não tradicionais de pesquisa, outros canais que promovem perspectivas alternativas sobre a contabilidade estão florescendo no mundo inteiro (ex.: congressos e internet). Para a autora, as metodologias positivistas dominam a literatura contábil; ela crê, porém, que os métodos qualitativos aplicados à história oral ou aos arquivos primários permitem a imersão crítica em uma nova área de pesquisa. Essa forma de análise mais crítica seria essencial para a compreensão dos fatos e fundamental para evitar o diletantismo e aprofundar a compreensão de aspectos marginalizados na literatura contábil.

Para Laughlin (1987), o domínio da visão positiva na contabilidade dificulta o avanço do processo contábil para uma compreensão mais subjetiva da realidade e do conhecimento na teoria contábil. Acentua essa limitação o fato de que os pesquisadores, por causa de pressóes institucionais, preferem produzir artigos que possuam métodos facilmente verificáveis, com o objetivo de alcançar uma publicação em vez de investigar aquilo que realmente gostariam de estudar e analisar (TUTTLE; DILLARD, 2007). Assim, não é por acaso que somente uma minoria de pesquisadores contábeis no país mostra interesse em recuperar fatos e fenômenos relacionados à atividade contábil no Brasil.

Monteiro (1998, p. 59) assinala que uma das principais razóes para o pouco interesse acadêmico brasileiro pelo estudo dos fatos contábeis históricos resulta da dificuldade de se trabalhar com arquivos privados de antigas casas comerciais, principalmente daquelas que eram controladas por estrangeiros, já que a maioria delas era empresa familiar e constituída sob a forma de sociedade limitada. Portanto, elas não estavam legalmente obrigadas a divulgar suas informaçôes contábeis. Mesmo assim, a autora chama a atenção para o fato de que náo se deve confundir a inexistência de antigos arquivos com seu desconhecimento, já que fontes existentes podem estar disponíveis 
não só no país como também no exterior. Essa é exatamente a função do historiador: "descobrir onde estão esses registros históricos".

Embora sejam dominantes pesquisas empregando a visão contábil positiva da contabilidade, que quase exclusivamente se orientam por uma quantificação estatística do estudo, nota-se limitação no tratamento dos dados em razão de não se levar em consideração a questão comportamental na determinação dos métodos de registros econômicos e administrativo de cada época. Essa deficiência prejudica uma justa avaliação dos fatos patrimoniais e, sobretudo, sua correta interpretação. Por esse motivo, a avaliação dos dados e variáveis influentes dessa pesquisa baseou-se nos conceitos e pressupostos que norteiam a Nova Sociologia Institucional. A plataforma teórica dessa abordagem enfoca as organizaçóes a partir de uma ampla rede de relacionamentos interorganizacionais e sistemas culturais, identificando o isomorfismo organizacional, isto é, o fenômeno pelo qual as organizaçôes se estruturam motivadas pelas exigências do ambiente.

A realização da presente pesquisa justifica-se por: a) se utilizar de dados primários para fazer uma pesquisa histórica sobre as práticas contábeis desenvolvidas por uma empresa que manteve grande influência e hegemonia social, política e comercial no estado do Ceará e adjacências durante o período Imperial do Brasil; b) documentar e trazer ao debate acadêmico instrumentos de avaliação e descrição da influência dos eventos políticos e econômicos sobre a institucionalização de hábitos e rotinas na Contabilidade; c) fornecer evidências concretas sobre as diferenças e semelhanças entre a contabilidade praticada atualmente e a contabilidade adotada na época abrangida pela investigação; d) permitir a construção de uma plataforma de pesquisas contábil em uma perspectiva alternativa à ontologia e epistemologia positivista, que incentiva predominantemente procedimentos de pesquisa quantitativos como metodologia de pesquisa.

Neste trabalho, são examinados fatos econômicos registrados, basicamente, em cinco livros contábeis da Casa Boris. Esses livros se referem, respectivamente, ao período de 1872 a 1887 e descrevem não só a eficaz estrutura de governança corporativa utilizada no controle gerencial da empresa, mas também a qualidade dos registros contábeis de ativos e passivos, bem como a gestão racional dos recursos financeiros e oportunidades de negócios. A questão de pesquisa deste estudo, portanto, se resume em analisar tais documentos contábeis - especialmente as práticas contábeis utilizadas pela Casa Boris na condução de seus negócios - e identificar os aspectos contábeis julgados relevantes e de interesse para a história da contabilidade brasileira.

Com relação aos procedimentos metodológicos, o estudo empregou uma abordagem descritivo-exploratória, adotando fundamentalmente uma perspectiva histórica dos fatos ocorridos, por meio da análise de dados em fontes primárias. Alguns historiadores mais críticos desprezam o uso de arquivos primários na pesquisa contábil, ao passo que Fleischman e Tyson (2003, p. 45) julgam-nos essenciais para a formulação, desenvolvimento e validação da própria teoria ou, então, para responder às ideias propostas por outros estudiosos. Para eles, a pesquisa histórica a partir de uma fonte primária equivale a embarcar com entusiasmo em um caminho de pesquisa no qual a viagem, em parte, pode ser tão gratificante como o produto final. Na opiniáo desses autores, a emoção de encontrar "tesouros enterrados" sob a forma de um documento-chave ou de uma carta, na maioria das vezes, é incomparável diante de outras formas de pesquisa acadêmica em contabilidade.

Para desenvolvimento da pesquisa foi selecionada a Casa Boris. As principais justificativas para seleção da amostra são: a) empresa secular, fundada no período objeto de estudo; b) existência de livros contábeis para estudo, em razoável estado de conservação; c) disponibilidade de realização da pesquisa, mediante solicitaçáo prévia e agendamento da visita; e d) oportunidade singular, na medida em que, nessa época, foram instaladas, no Brasil, diversas casas comerciais de controle estrangeiro. No caso da Casa Boris, a preservação de seu acervo documental representa uma situação bastante rara e feliz, já que seus principais livros contábeis encontram-se totalmente disponíveis para pesquisa acadêmica no Arquivo Público do 
Estado do Ceará. Portanto, essa é a motivação para se pesquisar neste artigo os arquivos dessa empresa.

O uso da abordagem histórica sobre os registros contábeis preservados ajudam a compreender sua importância econômica, política e social, já que, conforme os pressupostos e conceitos emanados da perspectiva institucional para o estudo das organizaçóes, as práticas contábeis podem ser explicadas como instrumento de legitimação de açôes e estratégias das organizaçôes (MOL, BURNS, MAJOR, 2006). Sendo documental o método de pesquisa aplicado neste trabalho, a investigação empírica está alicerçada em uma abordagem qualitativa voltada para a análise das principais práticas contábeis adotadas por uma empresa comercial controlada por uma família de origem francesa, vis-à-vis determinadas regras e legislaçóes vigentes no segundo período imperial brasileiro.

Quanto aos procedimentos de coleta de dados para o estudo, foram feitos em duas etapas de sete dias cada uma, ou seja, em duas semanas (a primeira em setembro de 2011 e a segunda em janeiro de 2013). Nessas duas ocasióes, além de se anotar as evidências detectadas, com a devida autorização, foram tiradas fotos do conteúdo dos livros para posterior verificação complementar das evidências obtidas ao longo do levantamento dos dados. Como segunda etapa da pesquisa, realizou-se a leitura e a análise crítica dos dados extraídos dos livros selecionados, com ênfase no exame: (a) das contas, lançamentos e históricos contábeis utilizados, observando todas suas características; (b) dos demonstrativos contábeis (Balanço Geral) preparados pela empresa nos anos abrangidos pela pesquisa; (c) dos saldos contábeis e suas respectivas movimentaçōes; e (d) das características formais intrínsecas e extrínsecas dos livros contábeis pesquisados.

De acordo com Vollmers (2003), a função do historiador é organizar os dados e evidências em ordem cronológica, colocando-os dentro da cultura dominante e do contexto social, político e econômico, na medida em que são conhecidos e explicados. As evidências encontradas nos documentos contábeis da Casa Boris revelam sua realidade econômica no período analisado, mostrando o papel desempenhado pela contabilidade como sistema de informação, uma vez que os principais dados fornecidos pelo sistema contábil, relativos às operações de comércio de importação e exportação, permitiam a adequada tomada de decisão e a manutenção de uma política comercial competitiva contra seus principais concorrentes.

\section{PRÁTICAS CONTÁBEIS DA CASA BORIS}

O acervo contábil da Casa Boris é precioso e relevante, sob todos os aspectos, já que contempla um ciclo histórico brasileiro que começa em 1872 e se estende por 112 anos, abrangendo várias das mutaçôes sociais, políticas e econômicas por que passou o país durante os regimes monárquico, republicano, ditatorial e democrático. No presente artigo, apresentam-se aspectos dos registros contábeis da Casa Boris no período 1872-1887, relativos a cinco livros contábeis dessa empresa: a) Razão 1872-1878; b) Razão 1878-1886; c) Diário 1876-1882; d) Diário 1882-1884; e e) Diário 1885-1887.

\section{I Características formais dos livros contábeis}

Os registros contábeis, tradicionalmente, são realizados em livros inspirados em "comprovaçôes” (SÁ, 1980, p. 11). A referência a esse critério é encontrada na documentação preservada da Casa Boris. Com relação aos aspectos contábeis da escrituração dos livros investigados, observou-se que eram mantidos conforme o arcabouço legal vigente, cumprindo as formalidades intrínsecas e extrínsecas da época. 


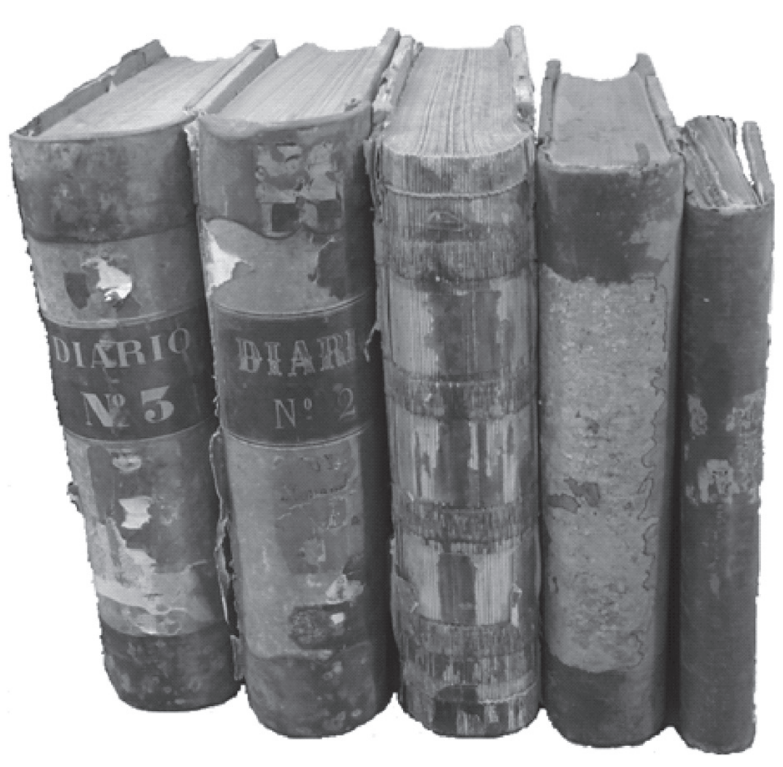

FIGURA 2 - Livros Diário e Razáo da Casa Boris

Fonte: Arquivo Casa Boris - ACB ([1878], [1882], [1884], [1886], [1887]).

A Lei no 556, de 25 de junho de 1850, que regulamentava a aplicação do Código Comercial do Império do Brasil, determinava a manutenção, de maneira uniforme, dos livros contábeis, visando à elaboração anual de um Balanço Geral dos ativos e passivos do negócio, que deveria ser datado e assinado pelo comerciante (Art. 10). Também prescrevia que a escrituração dos livros contábeis fosse feita em forma mercantil, em ordem cronológica de dia, mês e ano, sem intervalo em branco nem entrelinhas, bordaduras, raspaduras ou emendas (Art. 14). Segundo Schmidt e Santos (2008, p. 140), no entanto, o Código Comercial brasileiro não normatizou os procedimentos contábeis, apenas exigiu que as empresas brasileiras seguissem uma ordem uniforme de contabilidade e escrituração, mantendo livros necessários para esse fim.

Tecnicamente, a escrituração contábil da Casa Boris seguia os preceitos emanados da literatura da Escola Personalista, que segundo Cerboni (apud HERMANN JR., 1951, p. 35):

A Contabilidade, considerando a azienda em toda a sua extensão, na sua organização e nos seus fins, indagam-lhes as funções, determinam sob que critério deve ser baseado as várias responsabilidades dos administradores e dos agentes, e fornece os métodos e os meios com que se deve conhecer, medir, computar e demonstrar os resultados obtidos nos vários períodos da vida aziendal.

Para Mellis (1950), o início da contabilidade como ciência deu-se no século XIX, quando ocorreu o desenvolvimento de várias novas escolas de pensamento contábil. Entre as escolas de pensamento fundadas nessa época, está a personalista, também denominada por alguns estudiosos da contabilidade como logismográfica, jurídico-personalista ou toscana (SCHMIDT, SANTOS, 2008, p. 62). De acordo com Sá (1980, p. 26), a importância dada às "contas pessoais" nessa época era notória, quer na prática, quer na doutrina em vigor (admite-se, inclusive, que a criação do processo das partidas dobradas, cujo autor não se conhece formalmente, tenha derivado de uma "extensão" das contas pessoais àquelas de bens, através de débitos e créditos).

De acordo com Poisl (1996, p. 61-62), embora a personalização das contas tenha sido consequência de um fato historicamente real, o cuidado de se abrir contas de devedores e credores por ainda não se necessitar anotar os bens patrimoniais, ${ }^{2}$ a ideia de personificar as contas data das primeiras exposiçóes do método das partidas dobradas, mas sem o rigor científico da Escola do Personalismo contábil, já que se tratava de um mero artifício que os primeiros autores se serviram para explicar o mecanismo das contas.

Bacci (2002, p. 29) assinala que, dada as necessidades dos proprietários de representar seus bens dentro de uma ordem econômica, a classificação das contas segundo a Teoria Personalista dividia-se em contas do Proprietário (aquele a quem pertence a entidade e todo o Patrimônio Líquido), contas dos Agentes Consignatários (aquele a quem o proprietário tem a confiança na entrega de bens e valores materiais) e contas dos Agentes Correspondentes (aqueles terceiros com quem se mantinham relações de débitos e créditos).

Dentre os aspectos gerais que diretamente interessam à questão da formalização dos livros examinados para manutenção de seu valor probatório, verificou-se que os registros efetuados nesses 
livros estão escriturados pelo método das partidas dobradas, no idioma português, em escrita manual, sem nenhum erro ou rasura, com lançamentos de estorno, quando necessários, e seguem um modelo contábil baseado em uma abordagem personalista, em que a individualização das contas de credores e devedores era utilizada em um único lançamento contábil mensal, geralmente padronizado e detalhado histórico contábil da transação. Os termos de abertura e de encerramento evidenciavam concretamente a data do início da escrituração e o local ao qual se referia. A periodicidade de registro era mensal e os históricos dos lançamentos, comumente detalhados, possuindo quase todas as especificações das transações, o que propiciava um controle subsidiário, principalmente para fins de cobrança dos créditos, já que as contas individualizavam, com clareza, o nome do devedor e o montante devido por ele. O exercício social da Casa Boris tinha a duração de um ano e a data de término fixada no estatuto social era 30 de abril de cada ano.

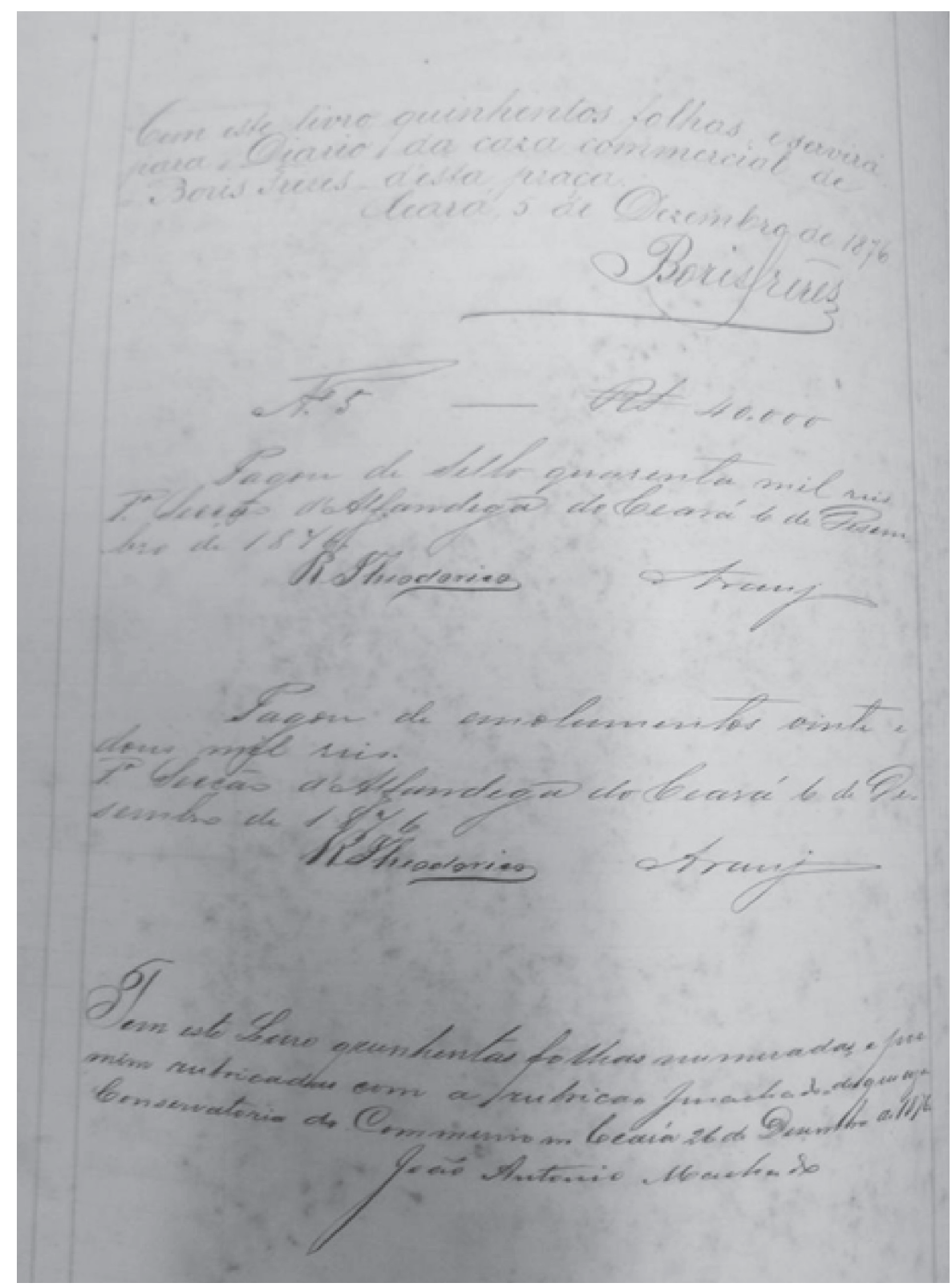

FIGURA 3 - Termo de abertura do Livro Diário (1876-1882) da Casa Boris

Fonte: Arquivo Casa Boris - ACB ([1882]). 
A forma de escrituração dos livros contábeis da Casa Boris obedecia a uma lógica de organizaçáo que envolvia as necessidades de gestão, em termos de numeraçôes e especificidades dos livros vis-à-vis a natureza das operaçôes. Para o adequado controle contábil dos lançamentos contábeis, havia a preocupação com a clareza e a confiabilidade dos dados (documentação sadia e convincente), que justificavam os registros econômicos efetuados (fatos e valores), empregando para tal o método das partidas dobradas, respeitando rigorosamente a cronologia dos fatos e fazendo-se sempre referência ao correspondente registro nos livros Diário e Razão.

QUADRO 2 - Descrição dos livros contábeis da Casa Boris

\begin{tabular}{|c|c|}
\hline Livros contábeis & Atributos \\
\hline $\begin{array}{l}\text { Razão usado no período } 1872-1878 \text { (ACB, } \\
[1878]) \text { : }\end{array}$ & $\begin{array}{l}\text { Encadernado em capa dura revestida de couro marrom escuro, em razoável estado de } \\
\text { conservaçáo, possui dimensóes de } 44 \mathrm{~cm} \text { de comprimento, por } 29 \mathrm{~cm} \text { de largura e } 5 \mathrm{~cm} \text { de } \\
\text { espessura. Pesa aproximadamente } 5 \mathrm{~kg} \text { e contém } 125 \text { folhas numeradas tipograficamente } \\
\text { em sequência, sendo sua fabricaçáo de origem francesa. Este livro contém, nas últimas } \\
\text { vinte e cinco folhas, um índice das contas e o número de folha correspondente, sendo que } \\
\text { cada conta utiliza duas folhas deste livro, com a página da esquerda sendo reservada para } \\
\text { os lançamentos a débito e da direita, para os créditos. }\end{array}$ \\
\hline $\begin{array}{l}\text { Razão usado no período } 1878-1886 \\
\text { (ACB, [1886]): }\end{array}$ & $\begin{array}{l}\text { Tem fabricação francesa (Fabrique de Registres Perfectionnes A. Sedille - Paris, sob o no } \\
\text { 37.154) e está em bom estado de conservação, encadernado em capa dura revestida de } \\
\text { couro verde com acabamentos metálicos nas pontas. Seu tamanho mede } 51 \mathrm{~cm} \text { de com- } \\
\text { primento, por } 39 \mathrm{~cm} \text { de largura e } 10,5 \mathrm{~cm} \text { de espessura, com um peso estimado em torno } \\
\text { de } 15 \mathrm{~kg} \text {, sendo suas } 500 \text { folhas numeradas tipograficamente e sequencialmente. }\end{array}$ \\
\hline $\begin{array}{l}\text { Diário usado no período } 1876-1882 \\
(\mathrm{ACB},[1882]) \text { : }\end{array}$ & $\begin{array}{l}\text { Encadernado em capa dura revestida de couro verde escuro com acabamentos } \\
\text { metálicos nas pontas, em bom estado de conservaçáo, possui dimensóes de } 51 \mathrm{~cm} \\
\text { de comprimento, por } 39 \mathrm{~cm} \text { de largura e } 10,5 \mathrm{~cm} \text { de espessura. Pesa aproxima- } \\
\text { damente } 15 \mathrm{~kg} \text { e contém } 500 \text { folhas numeradas tipograficamente em sequência, } \\
\text { sendo sua fabricação de origem francesa (Fabrique de Registres Perfectionnes A. } \\
\text { Sedille - Paris, sob o no } 37.153 \text { ). Este livro tem termo de abertura feito em } \\
5 / 12 / 1876 \text { (assinado como Boris Frères). Em } 06 / 12 / 1876 \text {, pagou } \$ 40.000 \text { réis } \\
\text { a título de selamento do Diário e } \$ 22.000 \text { réis como despesa de emolumentos, } \\
\text { conforme assinatura de dois funcionários da Alfândega (R. Theodorico e Araújo). } \\
\text { Posteriormente, em } 26 / 12 / 1876 \text {, esse livro foi registrado na Conservatória de } \\
\text { Comércio no Ceará (equivalente à atual Junta Comercial) conforme assinatura } \\
\text { e rubrica nas demais folhas feitas pelo deputado suplente da Junta Comercial Sr. } \\
\text { Joáo Antonio Machado. A rubrica das páginas do livro era feita no canto superior } \\
\text { da página esquerda. }\end{array}$ \\
\hline $\begin{array}{l}\text { Diário usado no período } 1882-1884 \\
\text { (ACB, [1884]): }\end{array}$ & $\begin{array}{l}\text { Encadernado em capa dura revestida de couro verde escuro com acabamentos } \\
\text { metálicos nas pontas, em perfeito estado de conservaçáo, possui dimensóes de } \\
51 \mathrm{~cm} \text { de comprimento, por } 39 \mathrm{~cm} \text { de largura e } 10,5 \mathrm{~cm} \text { de espessura. Pesa } \\
\text { aproximadamente } 15 \mathrm{~kg} \text { e contém } 500 \text { folhas numeradas tipograficamente em } \\
\text { sequência, sendo sua fabricação de origem francesa. Aberto em } 27 / 04 / 1882 \text { pelo } \\
\text { contador da Casa Boris, foi registrado na Junta Comercial em } 01 / 05 / 1882 \text {, tendo } \\
\text { sido subscrito pelo secretário José Candido Cavalcanti e suas folhas rubricadas } \\
\text { pelo deputado da Junta Comercial Sr. Joaquim Álvaro Garcia. }\end{array}$ \\
\hline $\begin{array}{l}\text { Diário usado no período } 1885-1887 \\
\text { (ACB, [1887]): }\end{array}$ & $\begin{array}{l}\text { Encadernado em capa dura revestida de couro verde escuro com acabamentos em metálico } \\
\text { nas pontas, em perfeito estado de conservaçáo, possui dimensóes de } 51 \mathrm{~cm} \text { de comprimento, } \\
\text { por } 39 \mathrm{~cm} \text { de largura e } 10,5 \mathrm{~cm} \text { de espessura. Pesa aproximadamente } 15 \mathrm{~kg} \text { e contém } 500 \\
\text { folhas numeradas tipograficamente em sequência, sendo sua fabricaçáo de origem francesa. }\end{array}$ \\
\hline
\end{tabular}

Fonte: Elaboração própria. 


\subsection{Ampla utilizaçáo de contas correntes}

No exame realizado nos livros contábeis, é interessante relatar que há muitos registros efetuados em contas correntes relativas a contas pessoais (correspondentes, proprietários e consignatários). No período 1878-1886 observa-se um significativo incremento do número de lançamentos contábeis relacionados com as contas de correspondentes e consignatários, em parte decorrentes do grande volume de vendas a prazo e de transaçóes com produtores agropecuários brasileiros na compra e/ou aquisição de produtos em consignação.

Ressalta-se que, apesar da intensidade de movimentaçóes em contas pessoais, os lançamentos contábeis indicavam o nome completo dos devedores e credores como título das contas contábeis, seguindo uma abordagem personalista, supostamente para se precaver frente à necessidade de apresentar valor probante para solucionar eventuais discussōes judiciais. Paralelamente, houve também a escrituração contábil no livro Conta Corrente, relativo aos períodos 1880-1882 (494 p.) (ACB, [1882]) e 1885-1887 (601 p.) (ACB, [1887]) e no livro Copiador de Conta Corrente, dos períodos 1884 (499 p.) (ACB, [1884]) e 1885-1887 (1.000 p.) (ACB, [1887]).

Registre-se que as informaçóes desses livros não foram cotejadas para confrontar com as extraídas dos livros que basearam o presente artigo. Dada, todavia, a seriedade com que a Casa Boris tratava as contas correntes e o controle sistemático de seus livros contábeis, seja por conceito ou por evidência na escrituração do movimento de valores em relação a cada pessoa, não foram detectados problemas graves de incongruência nos livros analisados.

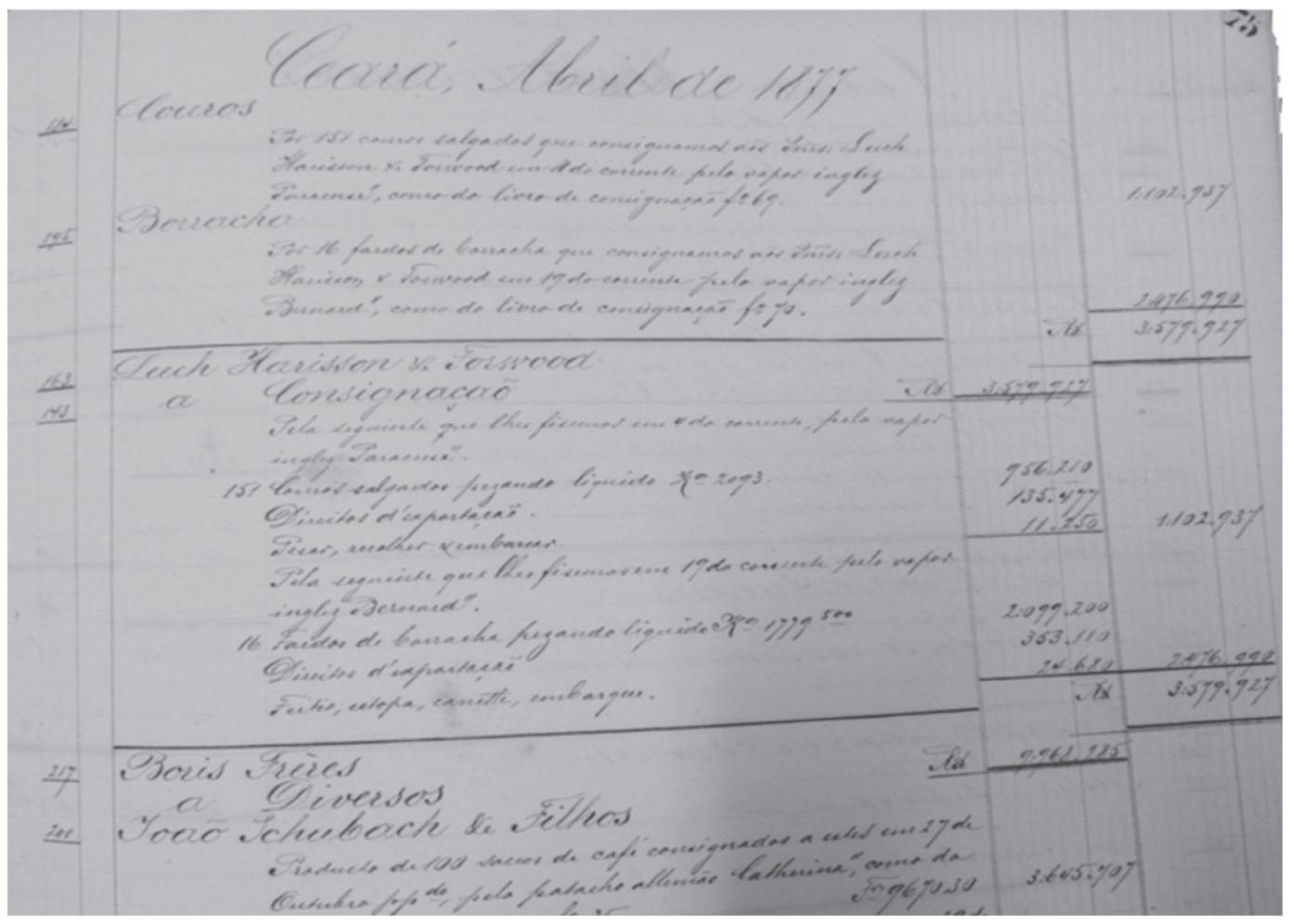

FIGURA 4 - Lançamento contábil de venda consignada para Leech Harrison \& Forwood

Fonte: Arquivo Casa Boris - ACB ([1878]).

As principais contas correntes colhidas nos livros analisados foram: Jaques Weil, Carlos Hardy Ceará Pedro Moraes Santiago Ceará, Manoel Pereira Valente Ceará, Bento Pereira Mendes
Ceará, Vários outros, Diversos Credores, Leech Harrison \& Forwood. Essa última conta referia-se às operaçôes de consignaçôes realizadas com esse comerciante de Liverpool, na Inglaterra, no 
período de maio/1878 a janeiro/1888, como mostrado na Fig. 4. Os lançamentos contábeis das mercadorias vendidas em consignação para este cliente estavam relacionados à negociação de sacos de cera de carnaúba, sacos de algodáo em pluma, além de barricas de caroços de mamona e barricas de resina de jatobá.

Em geral, como pode ser visto na Fig. 4, todos os gastos incorridos no processo de comercialização eram lançados na conta do freguês, inclusive as despesas alfandegárias de importação ou exportação como direitos municipais e provinciais. Também eram registradas as despesas com fretes e carretos, selos e despacho de conhecimento alfandegário, estampilhas, seguros, primagem (pagamento que se fazia ao comandante da embarcação), capatazia, barbante, corda, tinta, feitio de caixas, fardos, soldas de latas, telegramas e outros. Conforme Rego (2010, p. 201), todos os valores relativos a essas despesas eram anotados na conta do freguês, sendo posteriormente cobrado à vista ou até mesmo dividido em parcelas. No Razão analisado, foi identificada a utilização das contas "Alfândega", "Estampilhas" e "Seguros".

Com relação às vendas de mercadorias em consignação observa-se que os registros contábeis seguiam uma pauta de negócios realizados pela Casa Boris, principalmente relativas à exportação de matérias-primas, em diferentes épocas, como mostrado a seguir:

QUADRO 3 - Principais produtos vendidos por consignação pela Casa Boris — 1881 a 1886

\begin{tabular}{|c|c|}
\hline Ano & Produto \\
\hline 1881 & Trapos \\
\hline $1881-1882$ & $\begin{array}{c}\text { Courinhos, ossos, chifres, couros espichados } \\
\text { e garras }\end{array}$ \\
\hline $1882-1885$ & Mamona \\
\hline $1883-1885$ & Cera de carnaúba \\
\hline $1883-1885$ & Sal \\
\hline 1884 & Sola \\
\hline $1884-1885$ & Seda bruta \\
\hline $1884-1885$ & Sabonetes \\
\hline $1885-1886$ & Cacau e gêneros alimentícios \\
\hline
\end{tabular}

Fonte: Arquivo Casa Boris - ACB ([1886]).
Outras mercadorias encontradas nos lançamentos contábeis da Casa Boris foram oiticica (um tipo de mamona que dá um óleo muito bom), madeira de tatajuba, taboranás, açúcar, caroço de algodão, borracha, laranja, café, penas de ema e cabelos.

De um modo geral, as contrapartidas dos lançamentos em "Consignação" eram contas de correspondentes, cabendo citar, por exemplo, Jean Schuback de Fils, de Hamburgo, Alemanha, para quem eram feitas muitas exportaçóes em consignação de couro salgado. Mercadorias como café, algodão, penas de ema, gêneros diversos, cera de carnaúba, laranjas e borracha, dentre outras, eram registradas em várias contas consignadas (Carlos Hardy Ceará, Pedro Moraes Santiago Ceará, Manoel Pereira Valente Ceará, Bento Pereira Mendes Ceará, Vários outros etc.). Havia também uma conta relativa a "Consignaçóes de conta Alheia", utilizada pela Casa Boris para registrar as mercadorias que recebia para comercializar em nome de outros produtores ou estabelecimentos comerciais nacionais e estrangeiros.

As mercadorias exportadas e as remetidas para comerciantes de outras regiōes do país com os quais a Casa Boris mantinha relação comercial eram registradas como consignaçóes, que deveriam corresponder à forma contábil como eram remetidas aos vendedores. Esse sistema permitia que o remetente, no caso a Casa Boris, não perdesse a propriedade das mercadorias até que o vendedor conseguisse vendê-las para terceiros, momento em que deveria ser contabilizada a receita da venda, no montante acordado por ambos, deduzida da comissão a que o vendedor fizesse jus. Em outras palavras, as vendas em consignação eram feitas beneficiando a propriedade dos bens antes de sua efetiva venda pelos consignados, conforme exemplificado no lançamento contábil adiante, extraído do livro Diário da Casa Boris. 
NOME DO CONSIGNADOR

(Produtor Agricola da Região)

Saldo na data transação $(0)$
NOME DA MERCADORIA

(Couros, Mamona, Borracha, Cacau, etc.)

(0) Saldo na data transação $\mid 916.349$ (1)

BORIS FRĖRES PARIS

(3) $1,611.899$
NOME DO CONSIGNADO

(Leech Harrison; Jean Schuback ; etc.)

(2) $916.349 \quad 916.349$ (3)

LUCROS \& PERDAS

(1) $916.349 \mid$\begin{tabular}{l|} 
(3) $1.611 .899 \mid$ \\
\\
\\
(0) Pelo registro das mercadorias recebidas em consignação do produtor rural \\
(1) Pelo registro da operação constante do contrato de cessão das mercadorias em consignação \\
(2) Pelo registro do despacho por navio a vapor das mercadorias dadas em consignação \\
(3) Pelo registro da comunicação da venda feita pelo consignatário e registro do direito a \\
receber na conta de mútuo mantida com a Matriz na França
\end{tabular}

FIGURA 5 - Mecanismo contábil de registro de operações em consignação

Fonte: Arquivo Casa Boris - ACB ([1886]).

O uso da conta "Boris Frères Paris" no lugar de "Caixa" justifica-se porque, em geral, as operações de consignação eram realizadas com parceiros no exterior e quem efetuava a cobrança era a matriz em Paris. Portanto, o ajuste contábil ocorria na conta de mútuo entre as duas empresas, sendo absorvido por ocasião da remessa de produtos acabados pela empresa francesa para a filial brasileira.

Eram empregados também registros contábeis relativos a comissôes pagas a representantes comerciais que trabalhavam para a Casa Boris, sendo as principais contas utilizadas: "Comissão de Compras e Transporte por Terra", "Comissão de Compras e Transporte por Mar”, "Comissão de Açudes"; "Comissōes Ceará" e "Comissōes Boris Frères Paris”. Essa subdivisão é uma singela evidência de que a Casa Boris mantinha um incipiente sistema de Contabilidade Gerencial, haja vista manter controles paralelos para mensurar o resultado de diversas de suas atividades, mesmo sendo uma empresa comercial. No acervo documental da Casa Boris estão registradas informaçóes sobre valores pagos aos trabalhadores do porto e gastos realizados com serviços de embarque e desembarque, detalhando o tipo de trabalho, as contratações, o tipo de embarcação, as horas de trabalho e o salário pago aos contratados. Também havia o controle extracontábil por tipo de embarcação que fazia o serviço de transporte sobre a água, com seu respectivo "proprietário", a quantia paga de acordo com a carga transportada e as viagens realizadas; além de diversos documentos de controle de carga e descarga dos armazéns e navios, recibos fiscais de tributaçôes, apontamentos de recebimentos de mercadorias do interior, controle de gastos com mão de obra dos armazéns etc.

Dentre os fatos relativos a clientes que é interessante relatar, observou-se a cobrança de juros de $2 \%$ por atraso no pagamento de venda a prazo, sendo debitada a conta "Oriano \& Irmãos" e creditada "Delcredere", no valor de \$34.650 réis. Além disso, há um fato registrado no Diário e no Razão, em julho/1880, tendo havido um lançamento de crédito em Caixa relativo ao pagamento de uma casa dada em garantia pela dívida da conta de "João Cabral de Albuquerque", como pagamento de seu débito, no valor de $\$ 232.700$ réis. A conta debitada foi Bens Imóveis, porém não foi possível observar o registro de baixa da dívida (muito certamente, a transação deve ter sido escriturada por seu valor líquido). Com relação a esse fato, muitos comerciantes do Ceará, em suas transaçôes comerciais com a Casa Boris, pagaram 
dívidas com algodão, cera de carnaúba, penas de ema, couros, borracha e jaborandi. De acordo com Monteiro (2002, p. 220), para saldar suas dívidas junto à Casa Boris, resultante da compra de produtos manufaturados, quando passavam por dificuldades financeiras, se beneficiavam de um mecanismo muito frequente de pagamento de dívidas aceito pela Casa Boris, que consistia na quitação desse passivo mediante a entrega de matérias-primas ou bens realizáveis. Esse tipo de pagamento, segundo a autora, era tanto mais usual quanto mais descapitalizada era a economia brasileira, a ponto de o próprio Código Comercial de 1850 já dispor em seu artigo 354 que a letra de câmbio poderia ser paga em mercadorias.

\subsection{Contas de análise do resultado}

Para o encerramento do período contábil, a Casa Boris, a fim de evidenciar as variaçóes patrimoniais, empregava uma conta transitória de resultado denominada "Lucros e Perdas». Essa conta servia para registrar os resultados apurados de diversas contas, sendo encerrada ao final de cada período em contrapartida com um lançamento contábil na conta Capital. Observou-se que, no período analisado, não existia a conta Custos das Mercadorias Vendidas, sendo os ganhos e as perdas apurados pelo valor líquido, na sistemática usada para a apuração do resultado do exercício. Um exemplo foi a contabilização, em julho/1880, de uma transação de troca em que as mercadorias recebidas tinham valor superior ao valor contábil das mercadorias trocadas. No caso em questão, o ágio (lucro) cobrado na negociação foi creditado na conta "Lucros e Perdas", no valor de \$ 24.800 réis, contra um débito de Caixa. Cabe observar que nesse procedimento a conta Mercadorias não estaria evidenciando seu valor recuperável, haja vista que não foi feito nenhum lançamento contábil registrando a diferença a maior obtida com a troca das mercadorias.
Com relação às vendas, as contas usadas para retratá-las eram "Vendas a Dinheiro", "Gênero do País" e "Juros e Descontos". As contrapartidas dos registros efetuados na conta "Thesouraria da Fasenda" eram clientes que compravam a prazo. A empresa cobrava uma porcentagem de $2,5 \%$ pelas vendas de mercadorias a prazo, a título de "Delcredere". Os abatimentos concedidos eram lançados diretamente em "Lucros e Perdas". A conta "Fasendas Gerais" estava relacionada à movimentação de produtos já manufaturados (em geral importados da matriz francesa) e a conta "Diversos Gêneros" contemplava a movimentação de produtos in natura, tipo barricas de cera de abelha, crina de cavalo, urucu, couro, borracha, penas de ema, café etc. Observou-se que, em geral, essa conta era registrada com lançamentos de $2^{\text {a }}$ formula (vários débitos e um crédito), em nome de contas pessoais às quais se vendiam os produtos; não foi possível identificar se a Casa Boris possuía, ou não, algum sistema de inventário dos estoques, já que a conta "Fasendas Gerais" representava um conjunto de itens de mercadorias comercializadas pela Casa Boris (perfumes, vinhos, manteiga, livros, sapatos, roupas, artigos de cama e mesa, perucas etc.). Todavia, dado que no acervo dessa empresa constam livros específicos: "Mercadorias" (1894-1897), 500 p., e "Entrada de Mercadorias do Interior” (1883-1884), 200 p., além da manutenção de 105 caixas contendo documentação epistolar manuscrita que náo foi objeto de análise desta pesquisa, há a impressão da existência de um incipiente controle extra contábil dos estoques, haja vista que a atuação no grande comércio atacadista, tanto na venda de manufaturados importados como na compra de matérias-primas para exportação, demandaria da Casa Boris um mecanismo de controle de estoques bem eficaz para poder distingui-la das demais competidoras que haviam se estabelecido na Província do Ceará e garantindo-lhe sua sobrevivência durante décadas como de fato aconteceu. 


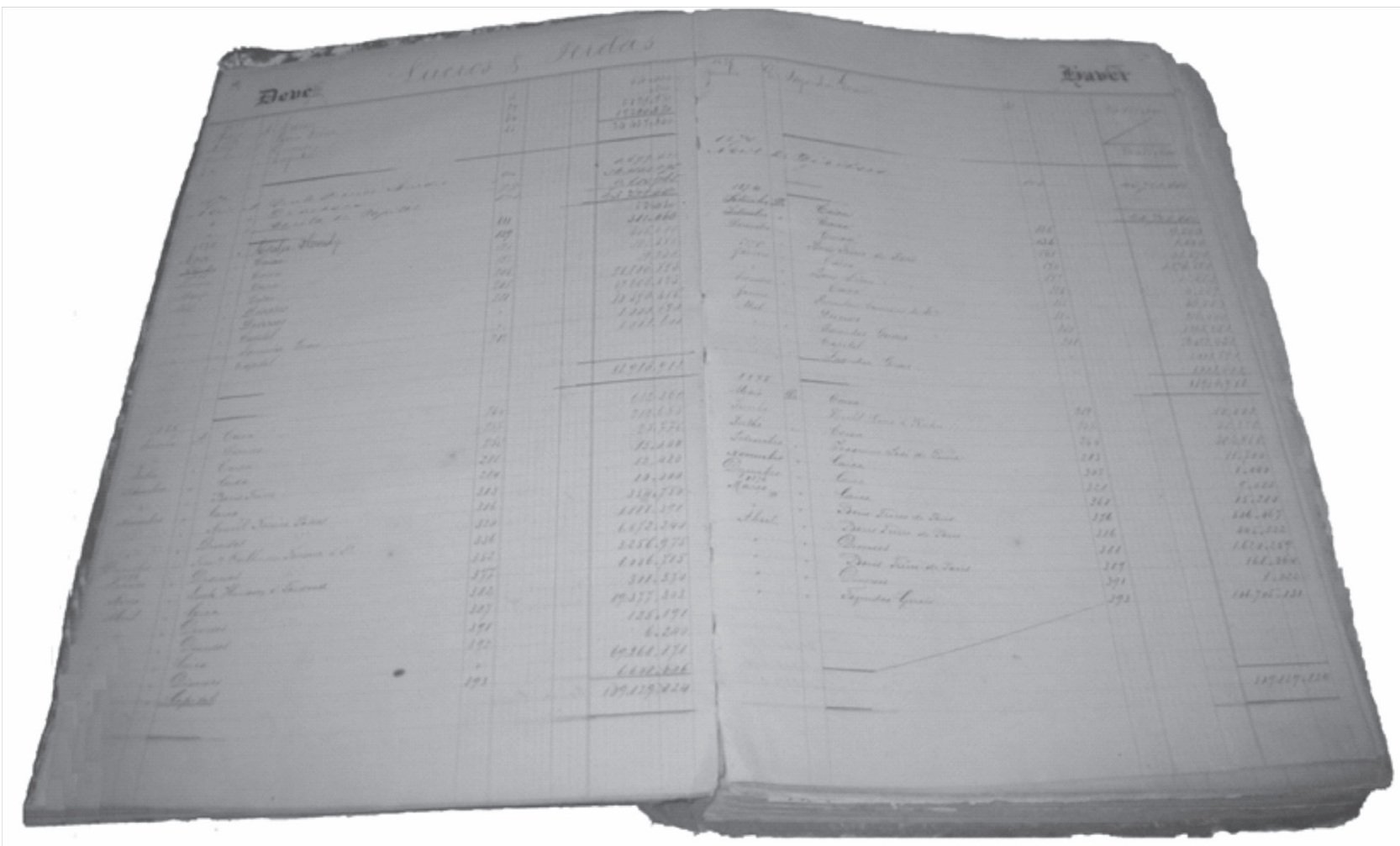

FIGURA 6 - Folha do livro razão (1878-1886) da Casa Boris

Fonte: Arquivo Casa Boris - ACB ([1886]).

Também chamou a atenção um lançamento efetuado em uma conta denominada "Estorno", que em janeiro/1875 foi debitada contra crédito na conta "Boris Frères de Paris", no valor de $\$ 238.842$ réis. Em abril/1875 foi creditada contra um débito na conta "Lucros e Perdas" nesse mesmo montante. Isso é um aspecto interessante a se destacar, já que, na prática contábil, o registro de estorno corresponde a lançamentos inversos, em que a conta anteriormente debitada é creditada, e a conta anteriormente creditada é debitada, não necessariamente pelo mesmo valor original, pois o estorno tanto poderia ser total como parcial. Os lançamentos de estorno visavam corrigir irregularidades e erros, atendendo aos preceitos do Código Comercial Brasileiro, que exigia obrigatoriedade de registros no livro contábil Diário e no livro Copiador de Cartas (o Razão, embora indispensável para a elaboração de Balanços e imprescindível para se entender os lançamentos contábeis, era considerado um livro de uso facultativo). Exemplos de registros de estorno encontrados nos lançamentos do Diário foram: a) escrituração errada em conta de outro cliente (debitou a conta de "Francisco Gaspar D'Oliveira" e creditou a conta de "Rodolpho Theophilo", valor $\$ 726.340$ réis); b) restituição de direitos tributários pagos indevidamente em julho/1880 (débito de "Caixa" contra de crédito "Alfandega", valor \$ 210.000 réis) e em maio/1881 (debito "Caixa" contra crédito "Alfandega", valor \$220.000 réis).

Em janeiro/1877, registrou-se na conta "Lucros e Perdas" eventos como: a) "dinheiro recebido e que julgavam perdido" (\$9.000 réis); b) "lucro feito na transação de câmbio com clientes" (\$ 59.310); e c) "dinheiro que trocamos tesouraria e já tínhamos passado ao débito desta conta" (\$ 20.200). Em outubro/1880, há uma reversão de perda lançada, debitando "Caixa" e creditando Lucros e Perdas. Esse lançamento foi relativo a uma letra dada em garantia pelo débito da conta "Padre João Augusto Scaligero de Maravallho", que a Casa Boris já havia provisionado como "Devedores Duvidosos". 


\subsection{Balanços e inventários}

Formalmente, a prática de escrituração contábil no Brasil origina-se na área pública, com a publicação da Carta Magna do Príncipe Regente D. João VI, em 1808, que fazia referência oficial à escrituração e relatórios contábeis por meio do método de partidas dobradas pelo Erário Régio.

No campo privado, a primeira referência de que se tem notícia na história brasileira data da promulgação, pelo Imperador D. Pedro II, em 1850, do Código Comercial Brasileiro, em que se regulamentaram os procedimentos contábeis a serem seguidos pelas empresas na escrituração dos livros contábeis (Lei no 556, de 25/06/1850, Art. 290).

Com a instituição deste Código, foi regulamentada, por primeira vez, a obrigatoriedade de as empresas comerciais escriturarem contabilmente suas atividades, elaborando anualmente demonstração do Balanço Geral, composto por seus bens, direitos e obrigaçóes (Art. 10). Nas diretrizes estipuladas nesse artigo do Código, exigiam-se a escrituração ordenada, sistemática e uniforme dos livros contábeis, visando elaboração anual de um Balanço Geral dos ativos e passivos do empreendimento, que deveria ser datado e assinado pelo comerciante (Art. 10, \$4). Os livros contábeis obrigatórios do comércio eram o Diário e o Copiador de Cartas (Art. 11). No primeiro livro, todos os fatos econômicos deveriam ser lançados com individualização e clareza para retratar as operaçôes de comércio e suas consequências e, no segundo, o comerciante estava obrigado a lançar o registro de todas as correspondências que expedisse, com as contas, faturas ou instruçóes que as acompanhassem (Art. 22). Ambos os livros deveriam ser encadernados, numerados, selados e rubricados em todas suas folhas por um dos membros do Tribunal de Comércio local, contendo termo de abertura e encerramento subscritos pelo secretário deste Tribunal e assinados por seu presidente (Art. 13). A escrituração desses livros deveria ser feita em forma mercantil, ou seja, por partidas dobradas, em ordem cronológica de dia, mês e ano, sem intervalo em branco, nem entrelinhas, borraduras, raspaduras ou emendas (Art. 14), sendo que a ocorrência de qualquer desses especificados vícios tornaria o livro nulo de fé jurídica (Art. 15).

Portanto, seguindo os preceitos legais determinados no Código Comercial (Art. 10), a Casa Boris, estava obrigada a elaborar anualmente o Balanço Geral de seus ativos e passivos, que deveria ser assinado por seus proprietários, devendo compreender todos os bens de natureza móvel e semovente, mercadorias, dinheiro, papéis de crédito e outra qualquer espécie de valores, bem como todas as dívidas e obrigaçóes passivas. O levantamento, a regularidade e a propriedade dos Balanços realizavam-se anualmente no mês de abril. A sistemática de levantamento do resultado era a seguinte: primeiro debitava-se " $\mathrm{Fa}-$ sendas Gerais" contra "Lucros e Perdas"; depois, creditava-se "Capital” contra "Lucros e Perdas"; em seguida, debitava-se "Balanço" contra crédito em "Devedores" e, também, creditava-se "Balanço" contra débito em "Credores". Com esses lançamentos cumpriam-se os preceitos legais, pois em lançamento subsequente, a empresa debitava "Devedores", detalhando todos os seus devedores (ativos) e creditava "Balanço". Também debitava "Balanço", creditando "Credores", detalhando todos os seus credores (passivos). Essa, pois, era a sistemática de apuração do resultado anual da Casa Boris. A título de exemplificação, mostra-se no Quadro no 4, o levantamento do Balanço Geral nos anos de 1880 e 1881 .

Observe-se, que, no caso do Passivo, o Balanço Geral da Casa Boris, ainda que não fizesse classificação em circulante e não circulante, seguia o mesmo ordenamento especificado atualmente na legislação societária vigente, apresentando as contas patrimoniais em ordem crescente de grau de exigibilidade dos elementos nele contidos. Iniciando pelos correspondentes credores, ordenados por ordem alfabética, e a conta de mútuo mantida com a matriz francesa (os Passivos Exigíveis), tinha em seguida a evidenciação das contas que afetavam o Patrimônio Líquido. 
QUADRO 4 - Balanço geral Casa Boris - em Réis

\begin{tabular}{|l|c|c|c|c|c|}
\hline Ativo & $\mathbf{3 0 / 0 4 / 1 8 8 1}$ & $\mathbf{3 0 / 0 4 / 1 8 8 0}$ & Passivo & $\mathbf{3 0 / 0 4 / 1 8 8 1}$ & $\mathbf{3 0 / 0 4 / 1 8 8 0}$ \\
\hline "Fasendas Gerais" & 475.627 .140 & 81.642 .370 & Credores $^{*}$ & 204.226 .321 & 160.697 .353 \\
\hline Devedores & 448.275 .677 & 423.648 .045 & Boris Frères Paris & 616.248 .758 & 380.488 .335 \\
\hline Isaye Boris & 1.615 .040 & - & Delcredere & 20.587 .665 & 1.345 .149 \\
\hline Achille Boris & 843.500 & - & Seguros & 3.498 .198 & 556.456 \\
\hline Bens Móveis & 3.660 .090 & 3.343 .430 & Conta de Câmbio & 14.054 .719 & 3.687 .705 \\
\hline Escravos & - & 765.720 & Capital & 139.873 .980 & 99.611 .320 \\
\hline Diversos Gêneros & 7.720 .424 & 6.435 .990 & & & \\
\hline Algodáo & 794.750 & - & & & \\
\hline Couro & 22.671 .790 & 20.626 .018 & & & \\
\hline Borracha & - & 582.700 & & & \\
\hline Penas de Ema & 913.900 & 142.500 & & & \\
\hline Café & 7.331 .342 & 4.358 .052 & & & \\
\hline Cernamby & 50.000 & - & & & \\
\hline Mangabeira & 100.000 & - & & & \\
\hline Bens Imóveis & 232.700 & - & & & \\
\hline $\begin{array}{l}\text { Companhia Ferro Carril do } \\
\text { Ceará }\end{array}$ & 5.000 .000 & 1.000 .000 & & & $\mathbf{6 9 8 . 4 8 9 . 6 4 1}$ \\
\hline Caixa & 23.653 .288 & 103.841 .493 & & & \\
\hline Total & $\mathbf{9 9 8 . 4 8 9 . 6 4 1}$ & $\mathbf{6 4 6 . 3 8 6 . 3 1 8}$ & & & \\
\hline
\end{tabular}

*Geralmente, todos os credores e devedores eram discriminados individualmente, nominalmente, em ordem alfabética.

Fonte: Arquivo Casa Boris - ACB ([1882)].

No tocante ao Ativo, seguia-se um critério e os bens e direitos estavam dispostos em ordem decrescente de grau de realização dos elementos nele registrados. Diante disso, primeiramente estavam apresentados os estoques ("Fasendas Gerais") e os consignatários devedores, em ordem alfabéti$\mathrm{ca}$, seguidos do fundo rotativo de caixa junto aos sócios. Em seguidas eram representados os ativos permanentes (móveis e imóveis) e as mercadorias mantidas em consignação e investimentos, finalizando com a conta Caixa, por ser líquida e certa, isto é, já estar realizada.

Dentre as contas correntes assinaladas no Balanço Geral, havia algumas relativas a transaçôes realizadas com outras instituições, como foi o caso de "Gabinete Cearense de Leitura", "Club Cearense", "Obras da Cadeia", "Palácio de Christal", "Reform Club" e "Estrada de Ferro Baturibé". Observou-se também o uso de outras contas, como a denominada "Seminário", que registrou lançamentos de crédito contra "Caixa" e "Fasendas Gerais", e das contas "Obras Públicas”, de novembro de 1881 até março de 1885 , e
"Empresa Funerária”, em 1881 e agosto de 1882. Por causa da personalização das contas a receber, todas essas contas são representativas de clientes institucionais, já que nos balanços daqueles tempos, apareciam também como "contas correntes”. Por exemplo, em abril/1881, tem um lançamento contábil registrando um débito na conta "Obras da Cadeia" e um crédito em "Fasendas Gerais”, no valor de $\$ 72.000$ réis, que muito provavelmente deve ter sido efetuado pela venda de produtos manufaturados importados para a referida instituição.

Outro aspecto a ser mostrado é a existência da conta "Companhia Ferro Carril do Ceará", que correspondia a um investimento em que a empresa tinha participação acionária. Nos razonetes seguintes, mostram-se alguns fatos escriturados nessa conta, ressaltando-se que esse ativo foi adquirido pelos irmãos Adriano e Achille, pelo valor de \$500.000 réis cada um, usando para isso o fundo de caixa rotativo a que tinha direito como sócio. 


\section{FERRO CARRIL}

(0) 1.000 .000
(1) 600.000 .000
(2) 400.000 .000
(3) 3.000 .000 .000
(4) 300.000 .000

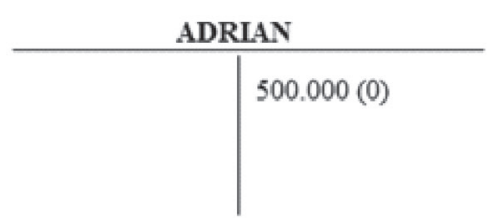

CAIXA

(0) Saldo na data transação
$600.000(1)$

$400.000(2)$

$3.000 .000(3)$

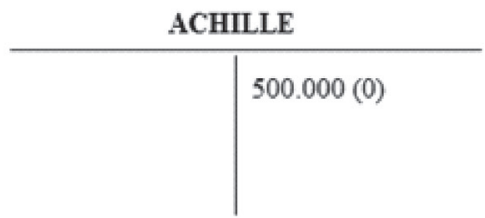

JUROS \& DESCONTOS

$300.000(4)$

(1) Pelo registro da aquisição do investimento, usando o fundo de caixa rotativo pessoal dos sócios Adrien e Achille

(2) Pelo aumento da participação societária no investimento, com pagamento à vista

(3) Pelo aumento da participação societária no investimento, com pagamento à vista

(4) Pelo aumento da participação societária no investimento, com pagamento à vista

(5) Pela apropriação de ganhos financeiros com a participação societária

FIGURA 7 - Lançamento contábil de investimento em outras sociedades

Fonte: Arquivo Casa Boris - ACB ([1882]), [1886]).

Vale destacar que não se identificou nas contas pessoais desses dois sócios o subsequente ajuste contábil de ressarcimento do valor investido inicialmente por eles. Notadamente porque muitas das despesas pessoais dos sócios eram pagas pela empresa e vice-versa, e a confrontação financeira poderia se dar de inúmeras maneiras. Para se ter uma ideia do funcionamento desse fundo de caixa rotativo, o quadro seguinte relaciona alguns eventos contábeis típicos registrados nessas contas ao longo das operaçóes normais da empresa:

QUADRO 5 - Exemplificação de transações constantes nas contas correntes dos sócios

\begin{tabular}{|l|l|}
\hline Nomes dos sócios & \multicolumn{1}{c|}{ Tipos de despesas } \\
\hline Achille, Alfhonse e Adrian & $\begin{array}{l}\text { Recebiam pagamentos em dinheiro e em espécie de mercadorias importadas, necessárias para uso } \\
\text { pessoal, do tipo chinelos, livros e cortinas. }\end{array}$ \\
\hline Achille, Alfhonse e Adrian & $\begin{array}{l}\text { Débito na conta "Fasendas Gerais" e crédito em "Gastos Gerais", no valor total de \$ 62.440 réis, } \\
\text { relativo a entrega de mercadorias para uso na casa dos irmáos: chita francesa, brim, argolas e três redes. }\end{array}$ \\
\hline Achille, Adrian e Isaye & $\begin{array}{l}\text { Algumas vezes, os sócios do Brasil tinham registros de compras de mercadorias a prazo lançadas a } \\
\text { crédito na conta "Fasendas Gerais", tendo como contrapartida um débito de um direito a receber da } \\
\text { Casa Boris contra seus nomes, como foi o caso de um registro de abril/1880 (Achille e Adrian) e outro } \\
\text { de outubro/1880 (Isaye). }\end{array}$ \\
\hline Adrian e Achille & $\begin{array}{l}\text { Era costume apropriar na conta "Gastos Gerais" as despesas dos sócios, como ocorreu em abril/1880 } \\
\text { em que foram contabilizados gastos particulares feitos no ano comercial nos valores, respectivamente, } \\
\text { de \$2.817.405 réis de (Adrian) e \$ 1.463.670 réis (Achille). }\end{array}$ \\
\hline Alfhonse, Adrian e Achille & Apropriação dos gastos particulares feitos pelos sócios durante o ano comercial. \\
\hline Isaye & $\begin{array}{l}\text { Lançamento de débito na conta "Fasendas Gerais" pela compra a prazo de mercadorias no valor de } \\
\$ 6.000 \text { réis. }\end{array}$ \\
\hline Adrian & Despesas com médico, álbum, boticário, carteira com navalha e alfaiate \\
\hline Achille & Gastos com boticário, alfaiate, fardamento, livros, conserto de relógios e chapéu de sol. \\
\hline Alfhonse & Despesa com boticário \\
\hline
\end{tabular}

Fonte: Elaboração própria. 
$\mathrm{Na}$ prática, os eventos relacionados aos proprietários eram escriturados em contas pessoais com a citação nominal de cada um deles. Nessas contas eram feitos lançamentos contábeis de fatos relativos às atividades comercial, profissional e privada, desses sócios, decorrentes de eventos relativos a seus gostos e estilos de vida particulares. Citam-se, por exemplo, despesas por conta de seus hábitos higiênicos e de consumo alimentício, bem como os gastos com vestimentas e mobiliário, material de escritório e despesas com a criadagem.

Diante disso, fica notório que os fatos econômicos relativos a eventos privados dos donos da empresa eram contabilizados como gastos e despesas da firma. Os registros citados mostram a ausência de preocupação em relação à obediência ao princípio da "entidade", que determina que o patrimônio da empresa não deve se confundir com o patrimônio de seus proprietários. Esse conceito, amplamente aplicado nos dias atuais como um dos princípios de contabilidade geralmente aceitos, só veio a existir formalmente no campo teórico na década de 1920, com a divulgação da tese de doutoramento de William Andrew Paton e a publicação de seus livros intitulados Principles of Accounting (1918) e Accounting Theory (1922). Talvez fosse essa a estratégia encontrada pelos sócios para remunerar o capital dos sócios (juros sobre o capital próprio), tendo em vista que não foram identificados registros contábeis de distribuição de pro labore ou tão pouco de pagamento de dividendos no período abrangido pelos livros analisados.

Com base nos dados coletados nos livros contábeis da Casa Boris, identificou-se que havia uma forma "camuflada" de remessa de lucros para o exterior através do mecanismo de confronto entre matriz e filial, a conta de mútuo (Boris Frères Paris), além de se observar que era praticada uma taxa de juros de $6 \%$ sobre a conta Capital para apropriação de uma remuneração mínima relativa ao custo de oportunidade do capital investido no negócio, equivalente ao atual conceito de juros sobre o capital próprio.

\subsection{Outros fatos contábeis destacáveis}

Além dos citados fatos patrimoniais, os registros contábeis da Casa Boris mostram o uso de várias outras contas como Caixa, Boris Frères Paris, Comissóes Ceara, Gastos Gerais, F. Boris Ceará, Lucros e Perdas, Massa de Jacques Weil, Alfândega, Delcredere, Juros e Descontos, Bens Móveis e Letras Descontadas. Em relação aos fatos econômicos retratados nessas contas, destacam-se alguns, conforme mostrado no quadro seguinte: 
QUADRO 6 - Evidenciação de algumas transações típicas da Casa Boris

\begin{tabular}{|c|c|}
\hline Data & Tipo de registro \\
\hline Abril/1880 & $\begin{array}{l}\text { Contabilizou a apropriação dos salários pagos durante o ano comercial aos funcionários Seraphim Coelho de } \\
\text { Souza Catunda, no total de } \$ 660.000 \text { réis, (seis meses a } \$ 30.000 \text { réis e seis meses a } \$ 80.00 \text { réis); João Gui- } \\
\text { lherme da Silva, no total de } \$ 660.000 \text { réis (idem, idem anterior); Argemiro Queixada, no montante total de } \\
\$ 400.000 \text { réis (cinco meses a } \$ 80.000 \text { réis); e José Fernandes Moura, no total de } \$ 424.580 \text { (seu ordenado } \\
\text { pelo tempo em que ficou na casa). Todos esses lançamentos foram efetuados tendo como contrapartida um } \\
\text { débito na conta "Gastos Gerais". }\end{array}$ \\
\hline Junho/1873 & $\begin{array}{l}\text { Aparece registrado, por primeira vez, um lançamento contábil de quarta fórmula }{ }^{3} \text { (débito de Diversos contra } \\
\text { crédito de Diversos) no valor total de } \$ 125.769 .310 \text { réis. Esse tipo de lançamento contábil, também conhe- } \\
\text { cido por "lançamento composto", foi criado pelo holandês Nicholas Petrie em } 1588 \text { (Jencks, 1954), porém } \\
\text { nunca teve grande divulgação mundial na época, pois os guarda-livros o consideravam de difícil entendi- } \\
\text { mento. Sua utilização prática evidencia o avanço técnico da contabilidade brasileira da época, e mostra que } \\
\text { os registros contábeis da Casa Boris estavam sob os cuidados de profissionais competentes e merecedores de } \\
\text { total confiança dos proprietários e gestores. }\end{array}$ \\
\hline Março/1885 & $\begin{array}{l}\text { Utilização da conta "Reserva" para registro de um débito contra crédito de "Boris Frères" no valor de \$ 7.200.000. Em } \\
\text { março de } 1886 \text { houve o lançamento a crédito nessa mesma conta, em contrapartida a um débito de "Balanço" no valor } \\
\text { de } \$ 7.200 .000 \text {. Supondo que Boris Frères se refira à "matriz" francesa, esse fato provavelmente corresponde à cobrança } \\
\text { de comissão por vendas efetuadas no Brasil. Nesse caso, o lançamento contra débito na conta "Balanço" [conta de "fecha- } \\
\text { mento" dos razóes para levantamento do Balanço] tem um crédito equivalente na "Demonstraçáo de Lucros e Perdas", } \\
\text { demonstrativo contábil que atualmente é substituído pela "Demonstraçáo do Resultado do Exercício". }\end{array}$ \\
\hline Junho/1873 & $\begin{array}{l}\text { Lançamento contábil de débito na conta "Capital", creditando as contas "Lucros e Perdas", no valor de } \\
\$ 17.001 .302 \text { réis e "Balanço", em \$ } 52.887 .958 \text { réis, perfazendo um montante total de \$ } 69.889 .260 \text { réis. } \\
\text { Tal fato parece se tratar de uma redução do Capital Social, como forma de absorver eventual prejuízo contá- } \\
\text { bil, haja vista que a conta Capital tinha a função hoje atribuída ao Patrimônio Líquido, ou seja, funcionava } \\
\text { na prestação de contas dos direitos e deveres dos sócios junto à empresa. Nessa mesma data, houve também } \\
\text { um lançamento de crédito na conta "Capital", debitando-se em contrapartida a conta "Câmbio" no mon- } \\
\text { tante de } \$ 4.072 .111 \text { réis e um lançamento de transporte de } \$ 65.817 .749 \text { réis. Esse segundo lançamento } \\
\text { parece se referir à incorporaçáo de diferenças cambiais ao capital social, derivadas ou oriundas de perdas com } \\
\text { operaçóes no exterior decorrentes das vendas por consignação efetuadas. }\end{array}$ \\
\hline
\end{tabular}

Fonte: Arquivo Casa Boris - ACB ([1878], [1886]).

Com relação às operações de câmbio, notou-se que decorriam das exportaçóes realizadas em consignação e eram contabilizadas no momento da cobrança pela matriz francesa. Observou-se que a sistemática de registro contábil dos efeitos de diferenças cambiais na data de fechamento da conta "Boris Frères Paris" era efetuada de forma um pouco atípica para os padrōes contábeis atuais, haja vista que as variaçóes ativas e passivas não eram registradas na própria conta patrimonial como usualmente se faz nos dias de hoje, e sim diretamente contra a conta Capital. O ajuste contábil dessa conta ocorria um pouco depois, por ocasião do encerramento do exercício contábil mensal da Casa Boris, empregando-se uma conta transitória denominada "Lucros e Perdas", na qual o resultado das variaçôes patrimoniais era contabilizado, para posterior transferência de encerramento e elaboração do Balanço Geral, tendo como contrapartida o lançamento na conta Capital. Nos razonetes seguintes, mostram-se os procedimentos contábeis adotados num lançamento contábil de um resultado com lucro numa operação de câmbio extraída, em abril de 1881, de um dos livros Diário da Casa Boris. 


\section{FERRO CARRIL}

\begin{tabular}{r}
\hline (0) 1.000 .000 \\
(1) 600.000 .000 \\
(2) 400.000 .000 \\
(3) 3.000 .000 .000 \\
(4) 300.000 .000
\end{tabular}

ADRIAN

$500.000(0)$

CAIXA
ACHILLE

$500.000(0)$

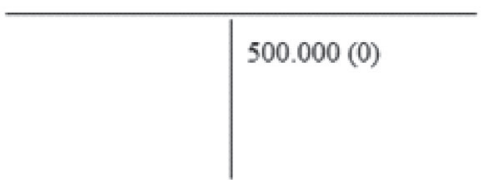

JUROS \& DESCONTOS

(1) Pelo registro da aquisição do investimento, usando o fundo de caixa rotativo pessoal dos sócios Adrien e Achille

(2) Pelo aumento da participação societária no investimento, com pagamento à vista

(3) Pelo aumento da participação societária no investimento, com pagamento à vista

(4) Pelo aumento da participaçăo societária no investimento, com pagamento à vista

(5) Pela apropriação de ganhos financeiros com a participação societária

FIGURA 8 - Lançamento contábil de operação de câmbio

Fonte: Arquivo Casa Boris - ACB [1886]).

Observe que a sistemática de registro contábil na conta "Lucros e Perdas" também contemplava a contabilizaçáo dos fatos como juros de mora cobrados, descontos concedidos, ganhos ou perdas nos ativos e passivos, bem como a apuração pelo valor líquido do resultado com mercadorias e produtos vendidos.

\subsection{Atividades subsidiárias}

A Casa Boris contabilizava também as operaçôes que realizava como comissionária de outras companhias. $\mathrm{Na}$ área de seguros, os lançamentos referentes às vendas de apólice eram efetuados debitando "Caixa" e creditando a conta de "Seguros". Por ocasião da prestação de contas à Cie l'Etoile de la Men, por exemplo, ela debitava "Seguros" e creditava a conta de mútuo "Boris Frères Paris", tendo em vista que seria a matriz na França que ficaria responsável pelo pagamento à companhia de seguros. Nesse registro contábil, colocavam-se os valores em franco na primeira coluna do Diário e especificava-se o câmbio da data da conversão do valor para a moeda brasileira (nesse citado caso específico, foram 246,30 francos ao câmbio de $\$ 465$ réis, dando um total de \$114.529 réis).
Em um evento no qual a Casa Boris atuava como agente de navegação ocorreu o naufrágio do barco Francis G. Daves, que transportava mercadorias e ficou avariado na praia de Periquara, no litoral de Paracuru/CE. Com isso ocorreu, em consequência, a urgência de venda imediata da carga no próprio local do acidente. Conforme Barroso (1973, p. 29), esse incidente foi o primeiro caso de sinistro marítimo documentado na história cearense e, talvez, na brasileira. Portanto, cumpriu-lhe defender os interesses da seguradora que representava.

Nesse fato, ocorrido no ano de 1878, utilizou-se a conta contábil "Massa de Jacques Weil”, homem de confiança dos irmãos Boris, que atuou como preposto da Casa Boris. Normalmente, nos processos de sinistro marítimo atuavam dois prepostos da Casa Boris, Jacques Weil e Ernesto Maeckert, colaboradores franceses de confiança que davam valiosa contribuição aos irmãos Boris, especialmente na fase decisiva de implantação e desenvolvimento da empresa no Brasil. Pessoas de temperamentos opostos, segundo Barroso (1973, p. 27), o primeiro era responsável pela substituição de qualquer um dos irmáos como correspondente da Casa Boris, quando houvesse necessidade de eles se ausentarem de Fortaleza, ao passo que o 
segundo, desempenhava múltiplas tarefas, principalmente no interior da Província, sempre que houvesse necessidade de solucionar questóes e casos das mais naturezas em nome da firma.

Esse processo de sinistro durou de 15/09/1978 a 13/12/1878. De acordo com Barroso (1973, p. 30), as mercadorias foram transportadas do barco para o local do leiláo (Praia de Paracuru) em carros de bois que atolavam na areia, náo tanto pela contingência dos ventos mas sim pela especulação do transportador, interessado em encarecer os serviços, para se beneficiar de méritos. O leiláo foi realizado satisfatoriamente, tendo Jacques Weil como leiloeiro. Para Barroso (1973, p. 30), isso representou um pioneirismo, sendo esse leiláo judicial marítimo o primeiro ato oficial dessa natureza na Província do Ceará, o que qualifica Jacques Weil como o primeiro leiloeiro oficial do Estado.

Como a Casa Boris atuava como comissionada nessa transação de seguros, não há registros contábeis relativos a esse fato, tendo em vista a perda não se referir a itens de seu patrimônio. Todas as despesas originadas desse processo de liquidação foram pagas diretamente por Jacques Weil, que nessa ocasiáo fez um saque de Caixa, em contrapartida a um débito em sua conta pessoal ("Massa de Jacques Weil"). Tal como acontecia no caso dos sócios, observou-se a apropriação na conta "Gastos Gerais" de despesas com boticário e pagamento e compras de roupas para seu criado, realizadas no ano comercial por Jaques Weil.

Também havia registro de operaçóes bancárias. Em março de 1886 a conta "Banco do Brasil" recebeu um débito contra crédito em "Francisco Barrozo Valente" no valor de \$ 10.000.000 réis. Depois houve um crédito nessa conta de \$10.000.000 réis, contra débito de "Caixa" no valor de \$ 3.997.170 réis e em "Balanço" no valor de \$ 6.002.930 réis. Esse registro está associado ao fato de a Casa Boris atuar também como casa comercial com função bancária, já que dispunha de capital e tinha estabelecido uma extensa rede de contatos alicerçada na distribuição de mercadorias, fosse na importação ou na exportação (MONTEIRO, 2009, p. 262). Através de seu sócio principal Theodore Boris, que na visão de Monteiro (2009, p. 261) era um homem que reunia qualidades de negociante-exportador, negociante-importador e banqueiro-negociante, a Casa Boris atuou como agente comercial do Banco do Brasil, recebendo uma comissão pelas transaçóes realizadas. Portanto, o crédito da conta Banco do Brasil para débito de Francisco Barrozo Valente (\$10.000.000) refere-se registro da intermediação financeira. O segundo lançamento foi necessário para espelhar a liberação do dinheiro ao tomador do empréstimo (\$3.997.170 réis) e a apropriação da comissão pelo exercício dessa atividade (\$ 6.002.930 réis), na conta Balanço.

Ao que parece, na data do pagamento da dívida pelo tomador do empréstimo (\$ 10.000.000 réis), a Casa Boris teria um débito de Caixa de $\$ 10.000 .000$ réis, tendo como contrapartida a quitação de um direito a receber do Banco do Brasil, de \$ 3.997.170 pelo uso de seu nome e marca como intermediador financeiro. Chama atenção a elevada taxa de juros cobrada ao cliente, em torno de $60 \%$ do valor emprestado, taxa muito parecida com as cobradas pelos agiotas nos dias atuais, que oferecem dinheiro fácil e sem burocracia, cobrando em troca juros mais altos do que os praticados pelos bancos e financeiras e fazendo uso de ameaça ou extorsóes para conseguir o pagamento da dívida.

\subsection{Contas do ativo permanente}

No tocante aos bens de características permanentes da Casa Boris, constatou-se o uso de quatro contas para evidenciar os fatos patrimoniais. A primeira é a conta "Bens Móveis", que era utilizada para o registro contábil das ferramentas, prensas, mobílias, máquinas e equipamentos usados nas operaçóes da empresa. Em seguida, estavam os "Bens Imóveis", que, em julho de 1880, apareceram registrados, pela primeira vez, com um lançamento contábil como ativos que eram utilizados para renda, tendo em vista que, em dezembro/1880, foi contabilizada uma receita de aluguel dessa conta, no valor de $\$ 12.000$ réis, relativa a dois meses de aluguel, e em abril/1881 registraram-se os aluguéis recebidos pela Casa Boris, referentes ao ano comercial, no valor de $\$ 24.000$ réis. Em terceiro lugar apareceram as contas que têm natureza de investimentos, como foi o caso da Ferrovia Ferro Carril do Ceará, já comentada no tópico 7.4 (Balanços e Inventários) 
deste trabalho. Por fim, tem-se uma conta bem atípica ao padrão de escrituração contábil moderno, que foi o registro, em setembro de 1875 , da conta denominada "Escravos".

É interessante ressaltar que a escravidão no Brasil foi regulamentada durante a fase do Império, por meio de um Projeto de Lei assinado por Antonio Pedro de Carvalho, datado de 07/07/1850, no Rio de Janeiro, onde era prescrita conservação de gente preta tanto livre como liberta e a colonização de africanos, em substituição à importação de escravos. A abolição deu-se em 13/05/1888, com a Lei no 3.353 (popularmente conhecida como Lei Áurea), que declarava extinta a escravidão no país.

\section{ESCRAVOS}

\begin{tabular}{r|c}
\hline (1) 850.800 & $850.800(2)$ \\
(3) 850.800 & $850.800(4)$ \\
(5) 850.800 & $850.800(6)$ \\
(7) 850.800 & $850.800(8)$ \\
(9) 850.800 & $480.000(11)$ \\
(10) 480.000 & $1.330 .800(12)$ \\
(13) 765.720 & $765.720(14)$
\end{tabular}

LUCROS \& PERDAS

\begin{tabular}{c|}
\multicolumn{2}{c}{ LUCROS \& PERDAS } \\
\hline (12) 85.080 \\
(14) 765.720
\end{tabular}

De acordo com Cosenza (1999, p. 135), os escravos eram registrados nos livros contábeis como aplicação de capital (ativos), contabilizados como "bens semoventes", tal como feito para o caso de animais como gado, touros para reprodução etc. Segundo esse autor, esses escravos recebiam marcação com um ferro em brasa (também chamada de carimbo) para registrar a marca de propriedade desses escravos. A marcação dos escravos, conforme Carreira (1983, p. 138), também era um sinal comprobatório de sua legalização, já que pela aposição do carimbo havia lugar à cobrança de um emolumento. $\mathrm{Na}$ contabilidade da Casa Boris, essa conta "Escravos" apresenta uma série de registros ao longo do tempo, como mostrado nos razonetes mostrados a seguir.

\begin{tabular}{r|l}
\multicolumn{2}{c}{ BALANÇO } \\
\hline (2) 850.800 & $850.800(3)$ \\
(4) 850.800 & $850.800(5)$ \\
(6) 850.800 & $850.800(7)$ \\
(8) 850.800 & $850.800(9)$ \\
(12) 765.720 & $765.720(13)$
\end{tabular}

(1) Pelo registro contábil, em setembro de 1875 , da aquisiçăo de uma escrava, com pagamento em dinheiro

(2) Pelo registro contábil, em abril de 1876, do inventário de encerramento da conta para elaboração do Balanço Anual do exercicio

(3) Pelo registro contábil, em maio de 1876 , da abertura da conta para inicio do novo exercicio anual

(4) Pelo registro contábil, em abril de 1877 , do inventário de encerramento da conta para elaboração do Balanço Anual do exercicio

(5) Pelo registro contábil, em maio de 1877 , da abertura da conta para inicio do novo exercicio anual

(6) Pelo registro contábil, em abril de 1878 , do inventário de encerramento da conta para elaboração do Balanço Anual do exercicio

(7) Pelo registro contábil, em maio de 1878 , da abertura da conta para inicio do novo exercicio anual

(8) Pelo registro contábili, em abril de 1879 , do inventário de encerramento da conta para elaboração do Balanço Anual do exercicio

(9) Pelo registro contábil, em maio de 1879 , da abertura da conta para inicio do novo exercicio anual

(10) Pelo registro contábil, em agosto de 1879 , da aquisição de um escravo "menino", com pagamento à vista

(11) Pelo registro contábil, em dezembro de 1879 , da venda do escravo "menino", com pagamento à vista

(12) Pelo registro contábil, em abril de 1880, do inventário de encerramento da conta para elaboração do Balanço Anual do exercicio, sendo contabilizado no resultado $10 \%$ de depreciação anual da escrava

(13) Pelo registro contábil, em maio de 1880 , da abertura da conta para inicio do novo exercicio anual

(14) Pelo registro contábil, em abril de 1881 , da perda no resultado pela baixa contábil da escrava por conceder sua liberdade

FIGURA 9 - Lançamento contábil da conta escravo

Fonte: Arquivo Casa Boris - ACB [1878]), [1882]), [1884]), [1886]). 
Cabe comentar que, por determinação do Código Comercial Brasileiro de 1850, a Casa Boris estava obrigada a elaborar e registrar em seu livro Diário um balanço patrimonial resumido de cada exercício social. Nos anos contemplados nesta pesquisa, constatou-se que a empresa preparava uma demonstração da sua situação patrimonial, apresentada no livro Diário sob o título "Balanço Geral”, mas na prática consistia em uma mera realização de lançamentos contábeis de "encerramento" das contas visando apurar o total de ativos e passivos a serem evidenciados no Diário. No início do novo exercício social se fazia o procedimento inverso, para estornar o registro contábil anterior de baixa e voltar a atribuir os devidos valores às contas contábeis. Em outra palavras, faziam-se dois lançamentos contábeis: a) débito de Balanço contra todas as contas credoras (Passivos); e b) crédito de Balanço contra todas as contas devedoras (Ativos). As contas que tinham incidência sobre o capital: Delcredere, Seguros, Câmbio, Comissões, Juros, Descontos, "Fasendas Gerais" ficavam fora desse procedimento porque tinham seus saldos confrontados com a conta Lucros e Perdas. E, por fim, a conta "Capital" recebia a transferência positiva ou negativa desse resultado de Lucros e Perdas.

Daí o fato de que na conta "Escravos", sistematicamente se "zerava" o saldo da conta em abril de cada ano e o mesmo era reaberto no mês de maio seguinte. Notadamente, houve de início uma compra de um ativo fixo (uma escrava) que tinha a função de trabalhar na residência dos Boris, em Fortaleza. Depois, sistematicamente, a partir de abril/1876, essa conta foi creditada contra um débito de "Balanço" no valor de $\$ 850.800$ réis. Tal fato deveu-se ao atendimento do dispositivo legal que exigia a elaboração anual da Demonstração do Balanço Geral, composto por seus bens, direitos e obrigaçóes. Da mesma forma, sempre no mês de maio, havia um débito contra "Balanço" no mesmo valor anterior do lançamento de abril, que era o procedimento contábil usado para a constituição dos ativos do novo exercício social e essa mesma técnica foi efetuada sistematicamente até abril/1881.
Em agosto/1879, "Caixa" foi creditada em razão da "compra de um escravinho de Luiz Felippe Cavalcante", ${ }^{4}$ no valor de $\$ 480.000$ réis. No mês de dezembro/1879 houve um débito de Caixa no valor de $\$ 480.000$ réis em contrapartida do crédito nessa conta. Nesse momento constatou-se uma divergência na escrituração contábil entre os livros Diário e Razão da Casa Boris, já que tal lançamento decorreu da venda do "escravinho" com lucro. $\mathrm{Na}$ análise a partir do livro Razão não é possível identificar o registro do lucro alcançado na operação, como pode ser constatado nos razonetes mostrados anteriormente.

Ao olhar, no entanto, o lançamento contábil no livro Diário, feito nessa mesma data, viu-se que o "escravinho" foi vendido por $\$ 500.000$ réis, tendo sido baixado $\$ 480.000$ réis da conta "Escravos" e contabilizados \$20.000 réis de ganho na conta "Lucros e Perdas". Também chamou a atenção o fato de que as despesas com a "nossa escrava" eram contabilizadas na conta "Gastos Gerais", assim como outras despesas como a do aluguel de um menino, dinheiro de um cozinheiro, aluguel da casa no 37 , aluguel da casa no 34 , comedoria, gás engarrafado, ordenado mensal Sr. Marckert etc. Cabe ainda comentar que os custos referentes aos impostos com a escrava também eram computados na conta "Gastos Gerais", contra crédito de "Caixa", como foi feito em fevereiro/1877, fevereiro/1878 e agosto/1879.

Em abril/1880, a Casa Boris começou a usar o critério de depreciação da conta "Escravos", empregando uma taxa de $10 \%$ sobre o valor do saldo da conta. Portanto, a conta de "Lucros e Perdas" sofreu um débito no valor de $\$ 85.080$ réis e "Balanço" um de $\$ 765.720$ réis, o que perfazia o valor total da escrava constante no momento de encerramento do exercício.

Parece, no entanto, que o contador da Casa Boris cometeu outro equívoco na escrituração do livro Razão, pois somou erroneamente, no lançamento, o custo contábil do "escravinho" que já havia sido vendido em dezembro/1879. O valor creditado na conta "Escravos" na transferência para fechamento do balanço foi de $\$ 1.330 .800$ réis, que equivaleria ao somatório do custo dos dois escravos, respectivamente $\$ 850.800$ réis e 
\$ 480.000 réis. Quando fez a constituição dos ativos para o novo exercício social, em maio/1880, a conta "Balanço" foi creditada somente pelo valor da escrava, em \$765.720 réis, que foi debitado contra "Escravos", ou seja, o erro foi corrigido.

Finalmente, em abril/1881, a conta "Lucros e Perdas" teve um débito no valor de $\$ 765.720$ réis, que segundo apurou-se no histórico do Diário foi relativo à perda pela concessão da carta de liberdade para a escrava. Registre-se que o conceito de depreciação também foi aplicado, a partir de abril/1880, aos bens fixos, no caso "Bens Móveis", que foi feita "pela desapropriação que estimamos nesta conta", 5 no valor de \$371.490, valor que equivaleria a $10 \%$ do saldo da conta.

\section{CONSIDERAÇÓES FINAIS}

As evidências coletadas no presente estudo contribuem para revelar a existência de um importante arquivo comercial preservado no Brasil, referente às atividades mercantis desenvolvidas na região Nordeste do Brasil por uma empresa familiar de controle francês, no período compreendido entre 1872 e 1887 .

A empresa em referência, popularmente conhecida como Casa Boris, atuou competitivamente no ramo de comércio atacadista, vendendo manufaturados importados e comprando matérias-primas para exportação, além de prestar serviços nas áreas bancária, seguradora e de navegação, ocupando posição privilegiada na economia cearense por mais de um século.

No tocante ao aspecto contábil, a pesquisa permitiu conhecer detalhadamente as principais características da "contabilidade" adotada pela Casa Boris, mostrando o efetivo papel desempenhado pelos registros e contas contábeis utilizados no processo gerencial dessa empresa.

Dentre os pontos relevantes detectados na análise dos livros contábeis pesquisados, citam-se: (1) sistema contábil moldado para funcionar como instrumento de apoio à gestão dos negócios e ao controle gerencial, permitindo registrar e sistematizar o grande volume de transaçóes comerciais resultantes das diversas atividades econômicas exploradas pela empresa; (2) práticas contábeis organizadas sob a influência de uma doutrina contábil individualista, que se baseava em um modelo contábil orientado para uma abordagem personalista dos credores e devedores na forma de descrição dos registros contábeis nos livros de contabilidade legais e subsidiários; (3) utilização de registros contábeis com conceitos ainda não prescritos na legislaçáo comercial brasileira da época, como depreciação, variação cambial, provisão para perdas e juros sobre capital próprio, dentre outros.

Além disso, o estudo permitiu documentar e resgatar parte relevante da história da contabilidade no Brasil e da história econômica do Ceará, mostrando que procedimentos contábeis praticados naquela época e que são amplamente divulgados nos dias atuais na literatura contábil existente já exerciam um papel relevante na contabilidade das casas comerciais brasileiras no período de transição do império para a república.

Baseado na análise do sistema contábil adotado pela Casa Bóris, conclui-se que, apesar da aparente simplicidade do sistema contábil utilizado, os controles contábeis serviam para monitoramento da evolução dos negócios e acompanhamento da evolução patrimonial, permitindo afirmar que: a) o sistema de escrituração contábil utilizado tinha foco no controle gerencial visando à tomada de decisão empresarial; b) o mecanismo de controle gerencial usado permitia monitorar a condução dos negócios e mensurar o resultado das atividades em termos globais e específicos; c) não havia preocupação com o atendimento ao princípio da entidade, haja vista o interesse em fazer a computação de gastos particulares dos sócios nas contas da empresa; d) já eram empregadas práticas contábeis bastante comuns atualmente, visando atribuir o valor justo aos ativos e passivos (provisão, depreciação e valor recuperável). 
A pesquisa também mostrou a ampla rede de relacionamentos interorganizacionais e sistemas culturais, revelando a influência das exigências do ambiente sobre as práticas contábeis da empresa e vice-versa, haja vista que foi detectado o uso de várias contas contábeis institucionais (Gabinete Cearense de Leitura, Club Cearense, Obras da Cadeia, Palácio de Christal, Reform Club, Empresa Funerária, Seminário, Obras Públicas e Estrada de Ferro Baturibé), que evidenciavam a influência de eventos políticos, sociais e econômicos sobre a institucionalização de hábitos e rotinas na contabilidade.

Embora a constituição da Casa Boris date de 1872 e este estudo tenha se restringido apenas ao período compreendido entre os anos de 1872 e 1887, essa empresa existiu e continuou operando em Fortaleza, capital do Estado do Ceará, até poucas décadas atrás. Por ter sido duramente atingido pela crise mundial de 1929, entretanto, o empreendimento inicial da Casa Boris foi afetado, forçando-a a operar praticamente apenas com os ramos de navegação e de seguros, fato que culminou com sua total extinção em 1984.

Desde sua fundação, a Casa Boris viu a primitiva Província do Ceará do Império brasileiro transformar-se no Estado do Ceará e foi palco e testemunha de grandes eventos da história brasileira, em termos econômicos, políticos e sociais. Em 25 de março de 1884, a então Província do Ceará antecipou-se ao Governo Imperial brasileiro e decretou o fim da escravidão, bem antes da promulgação da Lei Áurea, assinada em 1888. Nos registros contábeis da Casa Boris observou-se que a baixa e a concessão de liberdade para uma escrava contabilizada como um ativo permanente da empresa foi feita no exercício contábil de 1885.

Pelo fato de a Casa Boris ter mantido estreitas relaçôes com a elite política cearense, seja em termos econômico ou social, existem muitos desses episódios da história brasileira, que estão retratados indiretamente nos livros contábeis da Casa Boris, aguardando uma auditoria histórica mais profunda, que certamente auxiliaria o entendimento do ambiente geoeconômico do Estado do Ceará e da nação brasileira. A leitura dos fatos econômicos registrados nos livros contábeis da Casa Boris permite identificar corretamente as transaçóes comerciais realizadas por essa empresa em suas relaçóes comerciais durante o período analisado, descrevendo corretamente e com total transparência a coexistência de um comércio incipiente provincial com uma rede de vendas através do Atlântico para a Europa.

Como sugestão para futuras pesquisas sobre a história da contabilidade no Brasil, propóe-se considerar, especialmente, a influência da cultura francesa sobre a escrituração e a evidenciação contábil das empresas durante o período imperial brasileiro. Também se recomenda o desenvolvimento de futuros estudos analisando a história contábil brasileira a partir da identificação e análise dos documentos contábeis de outras casas comerciais instaladas no Nordeste, quanto em outras regióes do país, tendo em vista que várias casas comerciais francesas e inglesas se instalaram no Brasil durante o Período Monárquico.

\section{REFERÊNCIAS}

ALMEIDA, P. R. Os investimentos estrangeiros e a legislação comercial brasileira no século XIX: retrospecto histórico. Justiça \& História, Porto Alegre, v. 3, n. 5, p. 1-39, 2003. Disponível em: <http://www.tjrs.jus.br/export/poder_judiciario/ historia/memorial_do_poder_judiciario/memorial_judiciario_gaucho/revista_justica_e_historia/ issn_1676-5834/v3n5/doc/03-Paulo_Almeida. pdf>. Acesso em: 15 abr. 2012.

ARCHIVO CASA BORIS (ACB). Diário No 1: 1876-1882. Fortaleza/CE: Boris Fréres \& Cia Ltda., [1882]. 1.000 p.

Diário No 2: 1882-1884. Fortaleza/CE: Boris Fréres \& Cia Ltda., [1884]. 1.000 p.

Diário No 3: 1885-1887. Fortaleza/CE: Boris Fréres \& Cia Ltda., [1887]. 1.000 p. 
Razão No 1: 1872-1878. Fortaleza/CE: Boris Fréres \& Cia Ltda., [1878]. 247 p.

Razão No 2: 1878-1886. Fortaleza/CE:

Boris Fréres \& Cia Ltda., [1886]. 1.000 p.

BACCI, J. Estudo exploratório sobre o desenvolvimento contábil brasileiro: uma contribuição ao registro de sua evolução históricas. 2002. 175 f. Dissertação (Mestrado em Controladoria e Contabilidade Estratégica), Centro Universitário Álvarez Penteado, FECAP, São Paulo, 2002.

BARROSO, P. Um francês cearense. Fortaleza: Imprensa Universitária UFC, 1973.

BERTELLI, C. H. Uma casa chamada Boris. Rio Grande Filatélico, Porto Alegre, n. 45, dez. 2006. Disponível em: < http://www.sfrg.com.br/wp-content/uploads/2013/06/Uma-Casa-Chamada-Boris-Freres.pdf >. Acesso em: 22 ago. 2014.

BRASIL. Decreto n. 2.679, de 3 de Novembro de 1860. Rio de Janeiro: Coleção de Leis do Império do Brasil, 1860. p. 702, v. 1, pt. II. (Publicação Original). Disponível em: <http://www2.camara.leg.br/legin/ fed/decret/1824-1899/decreto-2679-3-novembro-1860-556786-publicacaooriginal-76916-pe. html>. Acesso em: 22 ago. 2014.

Lei n. 556, de 25 de junho de 1850. Código Commercial do Império do Brasil. Rio de Janeiro, Brasil: Colleção das Leis do Império do Brasil, 1850. t. 11, p. 57-238. Disponível em: <http://legislacao.planalto. gov.br/legisla/legislacao.nsf/Viw_Identificacao/ lim\%20556-1850? OpenDocument>. Acesso em: 22 ago. 2014.

CARREIRA, A. As companhias pombalinas: de Grão-Pará e Maranhão e Pernambuco e Paraíba. 2. ed. Lisboa: Ed. Presença, 1983.

COSENZA, J. P. A evoluçáo da escrituraçáo contábil através dos tempos: uma revisão histórica da Contabilidade contemporânea com base na literatura contábil. 1999. 183 f. Dissertação (Mestrado em Ciências Contábeis)- Faculdade de Administração e Finanças, UERJ, Rio de Janeiro, 1999.
FLEISCHMAN, R. K.; TYSON, T. N. Archival research methodology. In: FLEISCHMAN, R. K.; RADCLIFFE, V. S.; SHOEMAKER, P. A. (Eds.). Doing accounting history: contributions to the development of accounting thought. Netherlands: JAI, 2003. p. 31-47. (Studies in the Development of Accounting Thought; v. 6).

FRIDMAN, F. Judeus-franceses no Rio de Janeiro do século XIX. In: VIDAL, L.; DE LUCA, T. R. (Orgs.). Franceses no Brasil séculos XIX-XX. São Paulo: UNESP, 2009. p. 175-190.

GIRÃO, R. A funçáo comercial de Fortaleza. Fortaleza: Edição da Associação Comercial do Ceará, 1968.

História econômica do Ceará. 2. ed. Fortaleza: Casa José Alencar Programa Editorial, 2000.

HAMMOND, T. D. Histories outside the mainstream: oral history and non-traditional approaches. In: FLEISCHMAN, R. K.; RADCLIFFE, V. S.; SHOEMAKER; P. A. (Eds.). Doing accounting history: contributions to the development of accounting thought. Netherlands: JAI, 2003, p. 81-96. (Studies in the Development of Accounting Thought; v. 6).

HERMAN JR., F. Contabilidade superior. 3. ed. São Paulo: Atlas, 1951.

JENCKS, W. B. Historical dates in accounting. The Accounting Review, Sarasota, v. 29, n. 3, p. 486-493, July 1954.

LAUGHLIN, R. C. Accounting systems in organisational contexts: a case for critical theory. Accounting Organisations and Society, [S. 1.], v. 12 , n. 5, p. 479-502, 1987.

MARTINS, A. L. Presença imigrante francesa no Brasil: entre visôes do paraíso e mercado de trabalho. In: VIDAL, L.; DE LUCA, T. R. (Orgs.). Franceses no Brasil séculos XIX-XX. São Paulo: UNESP, 2009, p. 27-41. 
MAURO, F. As empresas francesas e o financiamento da industrialização do Brasil. Revista de Economia Política, São Paulo, v. 19, n. 3(75), p. 82-91, jul./set. 1999.

MELLIS, F. Storia dela ragioneria. Bologna: Zuffi, 1950.

MENEZES, G.R. Lutas políticas e crise social: a elite política cearense na década de 1879. 2006. 225 f. Dissertação (Mestrado em História Social), Universidade Federal do Ceará, Fortaleza, 2006.

MOL, J.; BURNS, J.; MAJOR, M. Intitutional theory. In: HOQUE, Z. (Ed.). Methodological issues in accounting research: theories and methods. London: Spiramus Press, 2006. p. 183-205.

MONTEIRO, D. M. O capital mercantil estrangeiro no Brasil do Século XIX: a atuação da Casa Boris Frères no Ceará. In: SZMRECSANY, T.; LAPA, J. R. A. (Orgs.). História econômica da independência e do império. 2. ed. rev. São Paulo: Imprensa Oficial SP, 2002. p. 197-234.

A Casa "Boris Frères" no Ceará. In: VIDAL, L.; DE LUCA, T. R. (Orgs.). Franceses no Brasil séculos XIX-XX. São Paulo: UNESP, 2009. p. 253-270.

Casas comerciais francesas no Brasil e na América Latina do século XIX: fontes para pesquisa histórica. America Latina en la Historía Económica, Coyoacán, v. 5, n. 9, p. 55-63, enero/ jun. 1998. Disponível em: <http://alhe.mora.edu.mx/ sistema/archivos/procesados/01-09-1998-0055.pdf>. Acesso em: 15 jan. 2012.

Comércio e diplomacia: o corpo consular francês na expansão comercial da França para o Brasil no Século XIX. Revista Pós-História, Assis, v. 2, p. 221-235, 1994.

MORAIS, N. M. Todo cais é uma saudade de pedra: repressão e morte dos trabalhadores catraieiros (1903-1904). 2009. 129 f. Dissertação (Mestrado em História e Culturas), Universidade Estadual do Ceará, Fortaleza, 2009.
MOTA, F.A.S. A secular Casa Boris e a importância de seu arquivo. Fortaleza: Secretaria de Cultura e Desporto, 1982.

NAPIER, C. J. The historian as auditor: facts, judgements and evidence. The Accounting Historians Journal, Tuscaloosa, v. 21, n. 2, p. 67-83, Dec. 2002.

POILS, E. A. A contabilidade como doutrina científica. Porto Alegre: Nova Prova, 1996.

REGO, J. M. A. N. Dos sertóes aos mares: história do comércio e dos comerciantes de Parnaíba (1700-1950). 2010. 304 f. Tese (Doutorado em história) - Universidade Federal Fluminense, Niterói, 2010.

ROCHA, L. M.; GANDARA, G. S. A presença francesa no Piauí do século XIX. História Revista, Goiás, v. 14, n. 1, p. 291-309, jan./jun. 2009.

SÁ, A. L. Aspectos contábeis no período da Inconfidência Mineira. Brasília: MF-ESAF, 1980.

SABA, R.N. P. F. As praças comerciais do Império e a aprovação do Código Comercial Brasileiro na Câmara dos Deputados. Revista Angelus Novus, Sáo Paulo, n. 1, p. 77-96, ago. 2010.

SCHMIDT, P.; SANTOS, J. L. História da contabilidade: foco na evolução das escolas do pensamento contábil. São Paulo: Atlas, 2008.

TAKEYA, D. M. O capital mercantil estrangeiro no Brasil do século XIX: a atuação da Casa Boris Frères no Ceará. Revista de Ciências Sociais, Fortaleza, v. 25, n. 1/2, p. 111-145, 1994.

Europa, França e Ceará: origens do capital estrangeiro no Brasil. Natal: UFRN Ed. Universitária, 1995.

TUTTLE, B.; DILLARD, J. Beyond competition: Institutional isomorphism in U.S. accounting research. Accounting Horizons, Sarasota, v. 21, n. 4, p. 387-409, Dec. 2007.

VOLLMERS, G. Accounting historiography using ancient sources: problems and rewards. 
In: FLEISCHMAN, R. K.; RADCLIFFE, V. S.; SHOEMAKER; P. A. (Eds.). Doing accounting history: contributions to the development of Accounting thought. Netherlands: JAI, 2003. p. 49-62. (Studies in the Development of Accounting thought; v. 6).

\section{NOTAS}

1 A grafia dos nomes dos sócios nos livros contábeis mudava segundo critério particular do contador que estava escriturando os fatos. Por exemplo, Adrien ora constava nos registros contábeis como Adrian e outras vezes como Adriano; idem para Theodore, Alphonse, Achille e Isaye, que tinham seus nomes aportuguesados para Teodoro, Affonso, Aquille e Isaie.

$2 \mathrm{Na}$ prática, mercadorias, dinheiro e bens em geral estavam sob as vistas vigilantes de seus donos, que não sentiam necessidade de manter contas regulares para o registro das mutaçôes patrimoniais.

4 Redação dada no histórico contábil, do lançamento constante do livro Diário da empresa.

5 Redação dada no histórico contábil, do lançamento constante do livro Diário da empresa. 